\title{
2005s-38 R \\ The Value of Real and Financial Risk Management
}

\author{
Marcel Boyer, M. Martin Boyer, \\ René Garcia
}

\begin{tabular}{c}
\hline Série Scientifique \\
Scientific Series
\end{tabular}

\author{
Montréal \\ Décembre 2005 \\ Version révisée en janvier 2007
}

(C) 2005 Marcel Boyer, M. Martin Boyer, René Garcia. Tous droits réservés. All rights reserved. Reproduction partielle permise avec citation du document source, incluant la notice (C).

Short sections may be quoted without explicit permission, if full credit, including $\mathbb{C}$ notice, is given to the source.
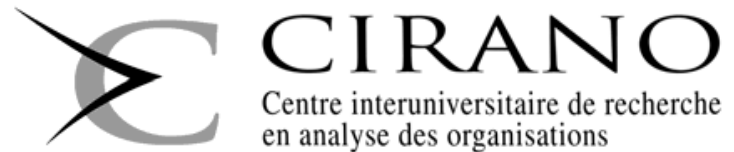

Centre interuniversitaire de recherche en analyse des organisations 


\section{CIRANO}

Le CIRANO est un organisme sans but lucratif constitué en vertu de la Loi des compagnies du Québec. Le financement de son infrastructure et de ses activités de recherche provient des cotisations de ses organisations-membres, d'une subvention d’infrastructure du Ministère du Développement économique et régional et de la Recherche, de même que des subventions et mandats obtenus par ses équipes de recherche.

CIRANO is a private non-profit organization incorporated under the Québec Companies Act. Its infrastructure and research activities are funded through fees paid by member organizations, an infrastructure grant from the Ministère du Développement économique et régional et de la Recherche, and grants and research mandates obtained by its research teams.

PARTENAIRE MAJEUR

\section{Les organisations-partenaires / The Partner Organizations}

. Ministère du Développement économique, de l’Innovation et de l’Exportation

PARTENAIRES

. Alcan inc.

. Banque du Canada

. Banque Laurentienne du Canada

. Banque Nationale du Canada

. Banque Royale du Canada

. Bell Canada

. BMO Groupe financier

. Bombardier

. Bourse de Montréal

. Caisse de dépôt et placement du Québec

. Fédération des caisses Desjardins du Québec

. GazMétro

. Hydro-Québec

. Industrie Canada

. Ministère des Finances du Québec

. Pratt \& Whitney Canada

. Raymond Chabot Grant Thornton

. Ville de Montréal

. École Polytechnique de Montréal

. HEC Montréal

. Université Concordia

. Université de Montréal

. Université du Québec

. Université du Québec à Montréal

. Université Laval

. Université McGill

. Université de Sherbrooke

AssociÉ À :

. Institut de Finance Mathématique de Montréal (IFM²)

. Laboratoires universitaires Bell Canada

. Réseau de calcul et de modélisation mathématique $\left[\mathrm{RCM}^{2}\right]$

. Réseau de centres d'excellence MITACS (Les mathématiques des technologies de l’information et des systèmes complexes)

Les cahiers de la série scientifique (CS) visent à rendre accessibles des résultats de recherche effectuée au CIRANO afin de susciter échanges et commentaires. Ces cahiers sont écrits dans le style des publications scientifiques. Les idées et les opinions émises sont sous l'unique responsabilité des auteurs et ne représentent pas nécessairement les positions du CIRANO ou de ses partenaires.

This paper presents research carried out at CIRANO and aims at encouraging discussion and comment. The observations and viewpoints expressed are the sole responsibility of the authors. They do not necessarily represent positions of CIRANO or its partners. 


\title{
The Value of Real and Financial Risk Management ${ }^{*}$
}

\author{
Marcel Boyer ${ }^{\dagger}$, M. Martin Boyer ${ }^{\ddagger}$, René Garcia ${ }^{\S}$
}

\section{Résumé / Abstract}

Nous caractérisons une entreprise comme un ensemble de projets avec les flux monétaires qui y sont associés. Les activités de production et d'exploitation de même que les activités de gestion réelle des risques distribuent ces flux entre divers états de la nature et périodes. Il en résulte une frontière des possibilités de transformation des flux similaire à une frontière de production. La concavité de la frontière amène la firme à réagir plus ou moins aux changements dans les prix des risques pour atteindre le nouveau portefeuille optimal d'activités réelles. La gestion financière des risques aide à implémenter ces modifications dans les projets et allège ainsi les problèmes associés de réorganisation et de coordination. Empiriquement, nous montrons que le degré de réactivité de la firme aux variations des prix des risques influence ses activités de couverture. De plus, nous montrons que la gestion financière des risques permet à l'entreprise de rencontrer des contraintes de cashflow-à-risque ou de valeur-à-risque à peu ou pas de frais.

Mots clés : gestion des risques, valeur de la firme, coordination, valeur à risque

We characterize a firm as a nexus of activities and projects with their associated cashflows. Production and operations activities and real risk management activities distribute cashflows over states of nature and time periods, leading to a transformation possibility frontier similar to a production function. The concavity of the frontier induces a firm to react more or less to changes in market prices of risks to attain the new value maximizing portfolio of real activities. Financial risk management helps implement these real project changes and alleviate the related reorganization and coordination problems. Empirically, we show that a firm's reactiveness to variations in risk prices is linked to its hedging activities. We also argue that financial risk management allows a firm to meet cashflow-at-risk or value-at-risk constraints at little or no cost.

Keywords: risk management, firm value, hedging, value at risk

Codes JEL : G22, G31, G34

\footnotetext{
* We thank Thomas Mariotti, Michel Poitevin, Richard Phillips, Gordon Sick, Sanjay Srivastava and Simon Van Norden for helpful comments on earlier versions of this paper, as well as seminar participants at Collège de France, Georgia State University, HEC Montréal, CIRANO, University of Toulouse 1, University Nova de Lisboa, the European Group on Risk and Insurance Economics, the Société canadienne de science économique, the World Risk and Insurance Economics Congress, the Northern Finance Association and the Financial Management Association. We also thank SSHRC, FQRSC and CIRANO for financial support. The third author acknowledges financial support from the Bank of Canada and MITACS.

† Bell Canada Professor of industrial economics, Université de Montréal, and Fellow of CIRANO and CIREQ, (marcel.boyer@cirano.qc.ca).

${ }^{\ddagger}$ CEFA Professor of finance and insurance, HEC Montréal, Université de Montréal, and Fellow of CIRANO, (martin.boyer@hec.ca).

${ }^{\S}$ Hydro-Québec Professor of risk management and mathematical finance, Université de Montréal, and Fellow of CIRANO and CIREQ (rene.garcia@umontreal.ca).
} 


\section{Introduction}

The objective, function and value of financial risk management remain debated issues. In 1993, the Group of $30^{1}$ recommended that market and credit risk management should be functions conducted independently of the day-to-day operations of a firm. Twenty years earlier, Mehr and Forbes (1973) argued the exact opposite. Today, Holton (2004) claims that the risk management function within a firm is too close to operations.

The modern academic view of risk management or hedging activities is mainly financial in nature and does not involve operations. However, chief risk officers are increasingly working alongside chief operating officers to maximize firm value, thus making enterprise risk management a central function. We propose a characterization of the firm where both risk management and operations management activities aim to maximize firm value.

In perfect financial markets, hedging risk cannot increase firm value. Smith and Stulz (1985) and Jin and Jorion (2006) discuss a hedging irrelevance proposition as an extension of the leverage irrelevance theorem of Modigliani and Miller (1958). In the absence of market inefficiencies, investors can undo any financial transaction undertaken by a firm so that firm value is independent of the risk management strategy (Titman 2002): a firm cannot create value by hedging risks since investors bear the same cost of risk as the firm.

Taxes, financial distress costs and/or agency costs are needed to justify hedging in a valuemaximizing firm. A firm facing a convex tax schedule increases its value by reducing, through risk management, the variability of its taxable earnings. Hedging can lower the expected cost of financial distress by reducing the probability of unfavorable outcomes. If hedging makes earnings less volatile, it lessens the information asymmetry and reduces agency costs (managers vs. shareholders, shareholders vs. bondholders, internal vs. external finance). ${ }^{2}$

\footnotetext{
${ }^{1}$ The Group of 30 is a private not-for-profit international body composed of senior representatives of industry, government and academia. See their 1993 study Special Report on Global Derivatives at www.group30.org.

${ }^{2}$ Several other reasons are found in the literature. Risk management can facilitate optimal investment and add value to a firm by favoring more stable free cashflows when the cost of external financing is higher than the cost of funding projects internally. Hedging may help retain valuable large shareholders or get stakeholders to make firm-specific investments. Stulz (2003) provides a systematic review of the various theoretical justifications for risk management within a firm. For the convexity of the tax schedule, see Main (1983), Smith and Stulz (1985), Graham and Smith (1999), Graham and Rogers (2002) and Graham (2003), as well as MacKay and Moeller (2003) for the case of general cost convexity. For the lower expected cost of bankruptcy or financial distress, see Booth et al. (1984), Smith and Stulz (1985), Block and Gallagher (1986), Mayers and Smith (1990), Nance et al. (1993), Geczy et al. (1997), and Bodnar et al. (1998). For signalling of managerial quality, see DeMarzo and Duffie (1995) and Breeden and Vishwanathan (1996). For managerial risk aversion, see Stulz (1984), Smith and Stulz (1985) and Tufano (1996). For improving the investment decisions and for better planning of a firm's capital needs, see Mayers and Smith (1987), Bessembinder (1991), Lessard (1991), Doherty and Smith (1993), Froot et al. (1993),
} 
Our representation of operations and risk management within a firm supports the view that financial risk management can add value even in a world with no taxes, no financial distress costs, and no information asymmetry. We start by describing a firm as a nexus of projects ${ }^{3}$ with their associated incremental cashflows. Projects are characterized by their respective level of expected cashflows and risk, which captures the correlation structure between the cashflows and risk factors faced by a firm. In this context, the object of production and operations management (POM) is to raise expected cashflows while real risk management (RRM) aims to lower risk. Based on this representation, we derive an efficient frontier in a space with expected cashflows and risk as coordinates, representing the set of efficient combinations or portfolios of feasible projects and activities selected by the real asset management (POM and RRM) functions of a firm.

Given the market prices of risk associated with risk factors, one can evaluate all feasible combinations of projects and arrive at the combination that maximizes firm value. Without market inefficiencies, there is still no role for financial risk management in maximizing value. As the market prices of risk change, however, a firm must adjust its portfolio of projects to achieve a new optimal position on its transformation possibility frontier. Depending on the shape of the efficient frontier this adjustment will be more or less pronounced. Movement towards the new optimal combination may lead to disagreements between the POM and the RRM units when expected cashflows must be reduced or risk increased in order to maximize firm value. We will show that financial risk management contributes to firm value by reducing coordination costs and by smoothing conflicts between the different firm functions. ${ }^{4}$ The costs of financial transactions are relatively small compared to the potentially high costs of reorganization. Therefore, even in a world with no taxes, no bankruptcy or financial distress costs and no agency conflicts between the different classes of stakeholders, there exist a value-adding role for financial risk management as a relatively inexpensive coordination tool favoring congruence of interests in the firm. ${ }^{5}$

Our setup establishes a definite link between hedging activities and changes in market paramand Holmström and Tirole (2000). Finally, for screening of informative earnings, see Doherty and Garven (2006). For a recent survey of the empirical evidence on the contribution of risk management to firm value, see Smithson and Simkins (2005).

${ }^{3}$ Projects may in some contexts correspond to the different business units or to different sets of activities within the organization.

${ }^{4}$ Garicano (2000, page 874) writes: "Organizations exist, to a large extent, to solve coordination problems in the presence of specialization. As Hayek (1945, page 250) pointed out, each individual is able to acquire knowledge about a narrow range of problems. Coordinating this disparate knowledge, deciding who learns what, and matching the problems confronted with those who can solve them are some of the most prominent issues with which economic organization must deal." See also Dessein, Garicano and Gertner (2006).

${ }^{5}$ The trade-off between specialization and coordination costs, both in information processing and acquisition, and the impact of such trade-off on organizational structure have been noted by many authors. See among others Becker and Murphy (1993), Bolton and Dewatripont (1994), Boyer and Robert (2006). 
eters, namely the risk free rate, the volatility of the risk factor return and expected risk premium. The use of financial instruments to hedge risk will be more pronounced when the efficient frontier is weakly concave since a small movement in the market parameters will then lead to an important adjustment in the optimal combination of projects. Therefore, a test will be to relate a concavity measure of the efficient frontier to the use of financial instruments across firms.

To gather empirical support for this proposition we collected a panel of accounting, financial and risk management data for 269 large U.S. firms for the years 1993 to 2004. We first construct a concavity measure of the efficient frontier for each firm, that relates the annual change in the position of a firm, in terms of expected cashflows and risk, to the change in the market price of risk. Using this measure, we first show that there is a strong relationship at the industry level between concavity and the use of derivative instruments. Second, using a ranked probit approach, we find that flexibility has a statistically significant positive impact on the number of operational risks that a firm hedges. This result holds even after controlling for other variables traditionally expected to have a significant impact on the use of financial derivative instruments, such as firm size, leverage, foreign exposure and convexity of the tax schedule. We also show that the number of business segments interpreted as a measure for coordination costs is a significant determinant of the number of operational risks hedged, even after controlling for firm size.

With respect to size, for instance, Bodnar et al. (1998), Nance et al. (1993) and Geczy et al. (1997) show that larger firms hedge more through the use of derivatives than smaller firms, even though their expected bankruptcy costs are relatively lower. Whereas Block and Gallagher (1986) and Booth et al. (1984) argue that larger firms engage in more financial risk management because of the large fixed costs involved to hedge financial risks, we argue instead that they do so because, relative to smaller firms, they experience more difficult coordination problems. Firms present in more business segments, such as multinational firms and conglomerates that have a more diverse project mix than single-industry single-country firms, will likely experience more important coordination problems, hence should be greater users of derivatives.

Another implication of our efficient frontier framework for analyzing the value of a firm concerns regulatory or self-imposed cashflows-at-risk $(\mathrm{CaR})$ or value-at-risk (VaR) constraints. We show that a firm can, through appropriate financial risk management operations, meet these financial constraints without affecting its value maximizing activities and therefore its market value. In other words, CaR and VaR constraints can be met without changing the optimal mix of real activities. This suggests that, because of the VaR and CaR constraints they face, firms in regulated industries such as financial services and public utilities will be heavier users of derivatives and other financial risk management instruments.

The fact that a firm can reduce risk through project choice is not new. Stulz (2004) mentions that a firm may give up highly profitable projects if they have the potential to increase 
substantially firm risk or choose unprofitable ones if they reduce risk. Stulz also mentions that risk reduction through project choice involves substantial costs. We capture this idea by drawing an efficient frontier between risk and expected cashflows. Our contribution is to show how the value of a firm is determined by linking the optimal portfolio of projects to the prices of market risk factors. We also link the relationship between project cashflows and risk to the concavity of the efficient frontier and to the changes in the market prices of risk factors. Our graphical device shows how hedging can make movements within the frontier easier and cheaper than costly reorganizations.

The efficient frontier captures implicitly both technological and strategic characteristics of a firm. Our representation measures the ability of a firm to change its risk through changes in its projects and/or operations, that is, to increase its value as it decreases its cash flow beta through those changes (Stulz 2004). For instance, flexibility in production could allow a firm to reduce its fixed expenses in cyclical downturns. Recently, Mackay and Moeller (2006) have pursued this idea and linked the concavity of revenues with respect to output prices to the usage of risk management instruments. In the same spirit, we define a measure of the flexibility of a firm through the concavity of its efficient frontier and we link this measure to the use of financial derivative products for hedging operational risks.

The remainder of the paper is organized as follows. We present the model of the efficient frontier and the value of a firm in Section 2. Section 3 discusses the reactiveness of firms to changes in the market price of risk and captures the coordination problems that may emerge between RRM and POM activities. It stresses the important role that financial risk management plays in alleviating these coordination problems. In Section 4, we conduct an empirical study to investigate the link between hedging activities and the concavity of the efficient frontier. Section 5 extends the analysis to related issues. We conclude in Section 6.

\section{The firm as a portfolio of projects}

\subsection{Preliminaries}

A firm is defined as a nexus of projects representing all real activities, such as those related to investment and production, and giving rise to a transformation possibility frontier for cashflows. This frontier is the envelope of all feasible vectors of cashflows over states of nature and time periods obtainable from all projects characterizing and identifying the firm as an economic entity. Hence, it accounts for all human, technological, contractual, legal and other constraints facing a firm. In the short term, a firm can modify its overall distribution of cashflows over states and time periods and switch from one distribution to another within its feasibility set by changing its project portfolio. In the long term, a firm can modify its feasibility frontier by changing constraints 
underlying the transformation possibility set, generally through technological and organizational innovations such as mergers, acquisitions and divestitures, or innovation and patent initiation.

If a firm can change its operations or increase its flexibility to significantly reduce its risk without changing expected cashflows, its market value will increase as the given expected cashflows will be discounted at a lower rate. Rather than characterizing a firm by a quasi-fixed and exogenously given risk measure, we see a firm as choosing, within its feasibility set, a portfolio of projects to obtain a distribution of cashflows that maximizes its value given the market prices of risk. We therefore approach risk management from the general viewpoint of the economics of the firm rather than from the usual financial perspective. ${ }^{6}$ We summarize the activities of a firm through the generated cashflows over states of nature and time periods.

To set ideas, we characterize in figure 1 a firm by two blocks, real asset management (RAM) and financial risk management (FRM). The first block is broken down into production and operations management on one hand, and real risk management on the other. All activities within a firm, such as project selection or self-protection, can be described along these two dimensions. Financial risk management is purposely set apart and involves all transactions carried out through the purchase or the sale of financial instruments.

\section{[Insert Figure 1]}

First, we show how to construct the efficient frontier for a firm. This will involve the choice of a risk model to characterize the trade-offs between expected cashflows and risk. For simplicity, we start with a linear factor model, valid period by period, where all sources of risk are priced. Next, we establish in this framework how to obtain the value of a firm. It will involve deriving an optimal portfolio of projects given the market prices of risk factors.

\subsection{The possibility frontier and the market prices of risk factors}

A firm is a technology by which cashflows $c f_{s t}^{p}$ related to various projects $p \in\{1,2, \ldots, P\}$ defining a firm as an economic entity are distributed over or transformed between different states $s$ and periods $t$, with $s \in\{1,2, \ldots, S\}$ and $t \in\{1,2, \ldots, T\}$, under technological, legal, or contractual constraints. The transformation possibility frontier of firm $j$ (i.e., the envelope of all feasible cashflow vectors) given its information set $\Omega_{0}$ at time $t=0$ can be represented as

$$
G_{j}\left(c f_{11}, \ldots, c f_{s t}, \ldots, c f_{S T} \mid \Omega_{0}\right)=0
$$

where $c f_{s t}$ is the aggregate cashflow over all projects $p$ in state $s$ and period $t$. The envelope of all feasible cashflow vectors is concave.

\footnotetext{
${ }^{6}$ In so doing, we develop a model of the firm in the spirit of the early contributions of Fama and Miller (1972) and Cummins (1976).
} 
A firm modifies cashflows through changes in its portfolio of projects. Characteristics of the vector of aggregate cashflows lead to the firm's evaluation by the financial markets. Given its technological possibilities represented by (1), a firm chooses the mix of POM and RRM activities to reach the vector of aggregate cashflows that maximizes its value. Hence, the frontier $G_{j}(\cdot)=0$ must be understood as the frontier that emerges from the POM and RRM activities. We later discuss the representation of financial risk management (FRM) activities in this framework.

For presentation clarity, we now describe a multifactor model with $N$ orthogonal risk factors so that their mutual covariances are zero. We also assume, for simplicity, constant expected cash flows per period, $E_{s}\left(c f_{s t}\right)=E_{j}, \forall t$, and an infinite number of periods. The rate at which these constant expected cashflows should be discounted is given by:

$$
E R_{j}=R_{F}+\sum_{i=1}^{N} \beta_{j i}\left(E R_{i}-R_{F}\right)
$$

where $E R_{i}$ is the expected return on risk factor $i, R_{F}$ is the risk free rate, and $\beta_{j i}$ is the measure of risk with respect to the $i$-th factor. In such a setting, firm value is simply:

$$
V_{j}=\frac{E_{j}}{E R_{j}} .
$$

Expressed in terms of cashflows, the security market line or hyperplane (2) takes the form:

$$
E_{j}=V_{j} E R_{j}=V_{j} R_{F}+\sum_{i=1}^{N} V_{j} \beta_{j i}\left(E R_{i}-R_{F}\right),
$$

where $V_{j} \beta_{j i}$ measures the risk of the firm's cashflows with respect to the $i$-th factor:

$$
V_{j} \beta_{j i}=V_{j} \frac{\operatorname{COV}\left(R_{j}, R_{i}\right)}{\operatorname{Var}\left(R_{i}\right)}=\frac{\operatorname{COV}\left(V_{j} R_{j}, R_{i}\right)}{\operatorname{Var}\left(R_{i}\right)}=\frac{\operatorname{COV}\left(c f_{j}, R_{i}\right)}{\operatorname{Var}\left(R_{i}\right)}=\frac{\operatorname{COV}\left(c f_{j}, R_{i}\right)}{\sigma_{i}^{2}} .
$$

We can rewrite (4) as

$$
E_{j}=V_{j} R_{F}+\sum_{i=1}^{N} \rho_{j i} \sigma_{j}\left(\frac{E R_{i}-R_{F}}{\sigma_{i}}\right),
$$

or

$$
V_{j}=\frac{1}{R_{F}}\left[E_{j}-\sum_{i=1}^{N} \rho_{j i} \sigma_{j}\left(\frac{E R_{i}-R_{F}}{\sigma_{i}}\right)\right],
$$

where $\sigma_{j}$ measures the volatility of the firm's cashflows and $\sigma_{i}$ measures the volatility of the market return on the $i$-th risk factor. The value of a firm depends, in this context, only on $E_{j}$ and the scaled correlations $S C O R_{j i}=\rho_{j i} \sigma_{j}$ between a firm's cashflows and market returns on the different risk factors.

Relative to valuing a firm, the variables $E_{j}$ and $S C O R_{j i} \equiv \rho_{j i} \sigma_{j}, i \in\{1,2, \ldots, N\}$, are the $N+1$ sufficient statistics of all projects within a firm. The transformation possibility frontier (1) can therefore be rewritten in terms of $E_{j}$ and $S C O R_{j i}$ as the envelope of all feasible points:

$$
H_{j}\left(E_{j}, S C O R_{j 1}, \ldots, S C O R_{j N}\right)=0
$$


We will work with this representation of a firm's technology. ${ }^{7}$

Defining a firm's feasibility set in terms of expected cashflows $E_{j}$ and the $N$ scaled correlation values $S C O R_{j i}$ has several advantages. First, it allows the value of RRM and POM activities to be measured from their capacity to move a firm toward or along the frontier $H_{j}(\cdot)=0$ in the $\left(E_{j}, S C O R_{j 1}, \ldots, S C O R_{j N}\right)$-space. A change in the mix of POM and RRM activities will usually generate a change of value. Second, it allows proper aggregation of risks at the firm level by establishing a functional relationship between risk factors and cashflows for the many projects or business units. Identifying risk factors that are common to the various projects and accounting for the dependencies between them is an important function in a firm, which can fall under the responsibility of a central unit or delegated to various units. The identification and measurement tasks are important functions of the chief operations officer, the chief risk officer and/or the chief executive officer.

\subsection{The value of the firm}

The value of a firm is generated by a mix of POM and RRM activities. For simplicity, one may represent operations management as being intent on maximizing expected cashflows for given levels of risk measured by the scaled correlations of a firm's cashflows with the $N$ different risk factor returns, thereby contributing to firm value. To contrast, real risk management may be seen as being intent on minimizing such scaled correlations for a given level of expected cashflows, thereby also contributing to firm value. Both groups of activities thus contribute to the overall objective of maximizing value. In reality, these functions are often diffuse in an organization and sometimes shared by the same division. In this context, the primary responsibility of higher level executives is to ensure that a firm's decision making process brings it on its frontier.

For further simplicity, let us assume that there is a single risk factor, namely the market portfolio risk. This will allow us to develop the main ideas in a simple graphical fashion. With $S C O R_{j M}=\rho_{j M} \sigma_{j}$, we can write (6) and (7) as: ${ }^{8}$

$$
\begin{gathered}
E=V R_{F}+V \beta\left(E R_{M}-R_{F}\right)=V R_{F}+S C O R_{M}\left(\frac{E R_{M}-R_{F}}{\sigma_{M}}\right), \\
V=\frac{1}{R_{F}}\left[E-\operatorname{SCOR}_{M}\left(\frac{E R_{M}-R_{F}}{\sigma_{M}}\right)\right] .
\end{gathered}
$$

From (9), we observe that $\beta \leq[\geq] 1$ as $S C O R_{M} \leq[\geq] V \sigma_{M}$. We can illustrate the problem of a firm in the $\left(E, S C O R_{M}\right)$-space as in Figure 2, where each dot represents a potential project with

\footnotetext{
${ }^{7}$ To draw, in practice, the efficient frontier for a given firm, one needs the set of cashflows associated with the numerous projects defining the firm along with the scaled correlations between the firm's cashflows and the returns on risk factors. Although the collection of such data is not a small task, some firms will undertake it, at least at some level of aggregation.

${ }^{8}$ We will drop the index of firm $j$ when the context is clear and no confusion is possible.
} 
a $\left(E, S C O R_{M}\right)$ pair of coordinates. All projects a firm can undertake are represented in that space where the frontier is constructed as the minimum level of risk obtainable for a given level of expected cashflows (see Merton, 1972) assuming that no project can make up more than $20 \%$ of the firm's portfolio of pojects.

\section{[Insert Figure 2]}

We can represent iso-value lines as in Figure 3. By definition, an iso-value line represents combinations of $E$ and $S C O R_{M}$ giving the same market value. From (10), iso-value lines are linear and parallel, with slope equal to the market price of risk

$$
\frac{E\left(R_{M}\right)-R_{F}}{\sigma_{M}}
$$

[Insert Figure 3]

The value $V$ attached to a given iso-value line can be obtained by discounting the zero- $S C O R$ expected cashflow level $\left(C_{1}\right.$ and $C_{2}$ in Figure 3$)$ at the risk-free rate $R_{F}: V_{1}=C_{1} / R_{F}, V_{2}=$ $C_{2} / R_{F}$. Firm value increases in the North-West direction.

The combination of expected cashflows $(E)$ and scaled correlation between cashflows and market returns $\left(S C O R_{M}\right)$ that maximizes firm value is the combination at which the efficient frontier reaches the highest iso-value line. For that combination (point $A_{2}$ on Figure 3 ), the usual tangency condition holds:

Proposition To maximize its value, a firm must equate its marginal rate of substitution, the rate at which it can substitute POM and RRM activities while remaining on its efficient frontier, to the market price of risk:

$$
-\frac{\partial(O M)}{\partial(R M)}=-\left.\frac{\partial E}{\partial S C O R_{M}\left(c f_{j}, R_{M}\right)}\right|_{H\left(E, S C O R_{M}\right)=0}=\frac{E\left(R_{M}\right)-R_{F}}{\sigma_{M}} .
$$

At $A_{2}$ on Figure 3, a firm cannot reduce its scaled correlation without reducing expected cashflows. At point $A_{1}$, however, the scaled correlation can be reduced without affecting expected cashflows because point $A_{1}$ is not located on the efficient frontier. A firm's POM and RRM strategies and policies are not efficient if they bring it to a situation such as point $A_{1}$. By better managing its real risk to reduce the scaled correlation of its cashflows, or by better managing operations to increase expected cashflows, a firm is able to increase its value.

It is obvious that a $\mathrm{N}$-factor linear model will be an immediate extension to the single risk factor model we just described. A firm will maximize its value at the point of tangency between an efficient hyper-frontier and the highest reachable iso-value hyperplane. In Section 5, we also discuss how to account for unpriced risk factors and sketch a general intertemporal risk model. 
For the purpose of illustrating the role of financial risk management and motivating our empirical application relating the efficient frontier to hedging activities, we will maintain a simple one-factor risk model.

\section{Firm flexibility, financial risk management and firm value}

Developments in the previous sections dealt mainly with real asset management. This section covers the role of financial risk management. Our main argument will be that financial risk management is a relatively inexpensive way to respond to changes in market conditions. Changes in the price of risk alter the portfolio of projects and activities that maximizes firm value; this creates coordination problems that the financial risk manager alleviates. Although the necessary changes in the portfolio of projects are the same with or without the presence of a financial risk manager, his presence allows the firm to achieve these changes at a lower cost. When the market price of risk changes, the extent by which a firm's portfolio of projects must change depends on the distance between the old and the new portfolio of projects. If the efficient frontier is relatively flat, the change in the optimal portfolio involves a rather important reshuffling of projects. On the opposite, a less important change is needed if the frontier is more concave. We will refer to the reactivity of the firm to changes in the market price of risk as the firm's flexibility; we present in the next section a way to measure this concavity-cum-flexibility measure of a firm's efficient frontier.

Whereas the transaction costs associated with financial instruments are low, changes in real asset operations through the implementation of new projects or the abandonment of existing ones typically entail substantial costs. Moving from one optimal portfolio of projects to another involves a complex set of trade-offs in terms of increasing or reducing cashflows and increasing or reducing risk among the many organizational units of a firm, each mixing production and operations management activities and real risk management activities. It may be the case that a production manager aims to maximize expected cashflows subject to attaining given levels of risk and wealth or to maximize a utility function subject to given levels of cashflows and risk. Several cashflows-at-risk or value-at-risk constraints may also be imposed at various levels in an organization. We argue through a simple graphical illustration that financial risk management reduces the cost of implementing the desired changes in real operations. As a result, firms that are more flexible are more likely to use financial derivatives to make real adjustments less costly.

To understand and model these complex interrelationships, one needs to rely on the general theory of decentralization in hierarchies and on the theory of incentives under incomplete information. However, the theory of incentives has not so far addressed the decentralization of risk 
management objectives. ${ }^{9}$ Moreover, aggregation of VaR targets in the risk management literature also poses difficult problems, even abstracting from incentive issues.

To develop our argument while avoiding an unnecessarily complex modeling of the structural interactions in organizations, we assume a separation of objectives between real risk management, intent on reducing the $S C O R$ value (that is, favoring projects that contribute to that goal), and production and operations management, intent on increasing the $E$ value. To illustrate the coordination problems associated with a change in the portfolio of projects, we assume that the real risk manager and the production and operations manager must agree before a project is chosen, added or abandoned.

The real risk manager will tend to oppose increases in risk $(S C O R)$ whereas the production and operations manager will tend to oppose reductions in expected cashflows $(E)$. Real risk managers, that is those managers who have responsibilities for inspecting facilities, drawing contingency plans, and designing and implementing self-protection and self-insurance programs, see their jobs becoming more difficult and demanding if the firm's $S C O R$ level increases. Hence, they tend to oppose (or even veto) changes in projects and activities that increase the $S C O R$ level, even if those changes are expected to be beneficial for the firm as a whole. Similarly, production and operation managers see their jobs becoming more difficult and demanding if the firm's $E$ level decreases. Hence, they tend to oppose (or even veto) changes in projects and activities that decrease the $E$ level, even if those changes are expected to be beneficial for the firm as a whole.

Such a representation of the conflict between RRM and POM functions is admittedly extreme. It nevertheless characterizes in a simplified way the difficulties encountered when various managers need to coordinate their choices to maximize value. Agreement between several functions before a project can be undertaken is common as major investments and policy or strategy decisions must gather a relatively large consensus among managers and executives. For instance, once a division manager or a business decision support group have produced the cash flow scenarios characterizing a proposed investment project, the project is generally analyzed and assessed by a risk evaluation committee and sometimes by the board itself. Only projects supported by the different instances can be implemented. ${ }^{10}$ The above simplified formulation is intended to represent such coordination procedures. ${ }^{11}$ We sketch below the coordination problems between

\footnotetext{
${ }^{9}$ See the recent survey of Mookherjee (2006)

${ }^{10}$ One can also think of coordination problems as being driven by organizational inertia, which emerges as different groups (or management functions) acquire quasi-veto rights on some changes in the activities of a firm. See Hannan and Freeman (1984) and Boyer and Robert (2006).

${ }^{11}$ In large corporations bonuses are usually linked to cashflow performance targets and less so to risk measures. Even option-based compensation rewards managers for cashflow performance to the possible detriment of real risk management activities. With respect to the compensation of real risk managers, Gable and Sinclair-Desgagné (1997) and Sinclair-Desgagné (1999) offer an audit-like procedure to assess managerial performance in the context
} 
RRM and POM in this simplified setting.

\subsection{Value creating coordination}

Suppose, for some reason, that a firm finds itself at a point on its efficiency frontier to the left of the optimal mix of POM and RRM activities as represented by point $A_{1}$ in Figure 4 .

[Insert Figure 4]

If the POM manager continues trying to increase $E$ for a given $S C O R$, while the RRM manager keeps working to reduce $S C O R$ for a given $E$, the firm as a whole finds itself trying to move in an infeasible North-West direction. The way out of this efficient but not value maximizing combination of POM and RRM activities is for the RRM manager to let the SCOR increase above its current level, providing the POM manager with some leeway to increase $E$. In so doing, the RRM manager must momentarily destroy value, by letting SCOR increase given E, giving the POM manager the flexibility to ultimately increase firm value. The same argument can be developed for point $A_{2}$. In this case the POM manager must let $E$ decrease below its current level. In so doing, the POM manager must momentarily destroy value) to give the RRM manager the possibility to reduce $S C O R$, thereby create value. In both instances, it is necessary for one manager to destroy firm value initially to allow the other manager enough room to eventually create more value. This level of coordination is clearly difficult as the first manager must assume some career risk.

\subsection{Flexibility and value creation through financial risk management}

We have thus far posited that in our framework with no taxes, no financial distress costs, no transaction costs of bankruptcy, and no agency problems, value is created within a firm only through its choice of real projects and activities. ${ }^{12}$ This means that maximal value is created only through an optimal mix of RAM activities, blending both POM and RRM ones. As the market price of risk changes, the optimal combination of expected cashflows and scaled correlation also changes, thus generating significant coordination problems as both the real risk manager and the production and operations manager must agree on changes. We will now show that financial risk management creates value by alleviating this coordination problem.

of environmental (real) risk management and control. An excellent cashflow performance of a manager may be penalized if the audit procedure reveals that it has been achieved to the detriment of proper risk management.

${ }^{12}$ This statement is clearly reminiscent of Proposition III in Modigliani and Miller (1958, page 288): “... the cut-off point for investment in the firm ... will be completely unaffected by the type of security used to finance the investment." 
Consider Figure 5. Suppose a firm's optimal mix is initially at $A_{2}$ but because of a change in the market price of risk, the new optimal mix is at $A_{0}$. Suppose, moreover, that the POM manager is unwilling or unable to destroy positive net present value projects (moving down) to provide the RRM manager with enough flexibility to reach point $A_{0} \cdot{ }^{13}$ How can financial risk management help in this process?

\section{[Insert Figure 5]}

Consider the iso-value line that goes through point $A_{2}$. This line is, by definition, lower than the iso-value line tangent to the possibility frontier at point $A_{0}$. The slope of iso-value lines is the price of risk, that is, the price at which one can exchange risk, SCOR, for expected cashflows $E$ on financial markets. Therefore, under conditions of perfect financial markets and in a manner similar to an individual's portfolio choice under the two-fund separation approach, a firm can enter into financial transactions to move from $A_{2}$ to any point on the same iso-value line. These movements, for example to point $B$, are done at no cost but do not affect firm value since financial transactions are not creating value per se.

The advantage of moving a firm's $(E, S C O R)$ combination to point $B$ is that the RRM and POM managers are then given the mandate to move the firm from $B$ to $A_{0}$. What then is the value of financial risk management? In and of itself, the value is zero. Its value comes from the fact that it reduces the coordination costs to attain a new mix of risk and expected cashflows. Moving from $A_{2}$ to $A_{0}$ requires abandoning [accepting] some projects with positive [negative] net present value given the $S C O R$-coordinate at $A_{2}$, hence the normal opposition of the POM manager to those changes. Similarly, moving from $A_{1}$ to $A_{0}$ requires abandoning [accepting] some projects that are risk reducing [increasing] given the $E$-coordinate at $A_{1}$, hence the natural opposition of the RRM manager to those changes. But given the new $E$ and $S C O R$ coordinates at $B$, the real changes in the project mix to move the firm from $B$ to $A_{0}$ can now be agreed upon by both managers: the real changes are the same but they can be achieved at lower coordination costs.

\subsection{An application to $V a R$ and $C a R$ constraints}

Financial risk management also allows a firm to obey some regulatory or self-imposed constraints on acceptable probability of losses. For instance, a cashflow-at-risk constraint imposes the requirement that the cashflow shortfall $E(c f)-c f$ will surpass a desired level $(C a R)$ with a given probability $\alpha: \operatorname{Pr}[E(c f)-c f>C a R]=\alpha$. These constraints, when binding, are usually perceived as preventing the maximization of firm value. Every $(E, S C O R)$ combination can be associated with a $C a R$ value. Iso- $C a R$ curves, that is curves on which all points have the same

\footnotetext{
${ }^{13}$ Similarly, if we start at point $A_{1}$, the RRM manager is unwilling to create risk and destroy value to give the POM manager enough flexibility to reach point $A_{0}$.
} 
$C a R$ value, can be drawn. On Figure 6, the $C a R$ value at point $A_{H}$ is the same as at point $D$. Let us identify this curve as $C a R_{H}$ and suppose that a firm is required to satisfy that $C a R_{H}$ level.

[Insert Figure 6]

A firm's value is not maximized at point $A_{H}$ since the iso-value line through $A_{H}$ lies below the iso-value line through $A_{L}$, the value maximizing point. The project mix in $A_{L}$ is certainly attainable given the possibility set of the firm, but $C a R_{L}$, the iso- $C a R$ curve through point $A_{L}$, does not satisfy the constraint. As a result, the difference in firm value between $C_{L} / R_{F}$ and $C_{H} / R_{F}$ represents the cost of the $C a R$ constraint.

With perfect capital markets, a firm is always able to trade zero-value financial contracts at no cost to move along the iso-value line whose slope is the market price of risk. Then, such a movement with financial instruments along the iso-value line going through $A_{L}$ can bring the firm to point $D$, which satisfies the $C a R$ requirement. At point $D$, firm value is equal to $C_{L} / R_{F}>$ $C_{H} / R_{F}$ since point $D$ lies on the same iso-value line as $A_{L}$. Again, value is not created by financial risk management per se. It simply makes a firm obey a $C a R$ constraint while keeping its optimal mix of real activities. This would have been infeasible without the use of financial instruments.

Therefore, $C a R$ constraints should have no impact on the market value of firms under perfect capital markets. Hence, a firm should instruct its real asset managers (POM and RRM) to maximize its value and then ask the financial risk manager to use financial transactions to satisfy the $C a R$ requirement. Consequently, financial risk managers in industries with binding $C a R$ regulation, such as the financial services industry, will or should be asked to purchase zero net present value financial contracts that reduce a firm's risk and expected cashflows (typically from $A_{L}$ to $D$ in Figure 6 ) in order to attain the risk-return constraint set by the regulatory body, at no cost in terms of firm value.

\section{Empirical evidence on the link between firm flexibility and hedging}

Assuming that a firm can gather all the necessary information about future cashflows associated with its numerous projects, current and future, and given a risk model, it can construct at any time the type of efficiency frontier we have described in the previous sections. Obviously, this is not an easy and straightforward task. We analyze some of the difficulties in section 5.2 below. It is much harder to gather a panel of such data sets for several firms. Therefore, to test some implications of our characterization of the firm, we must take an indirect approach.

The important empirical implication of our theory is that more flexible firms, having less concave possibility frontiers, will want to adjust their $(S C O R, E)$ position by larger margins when the market price of risk changes. Figure 7 illustrates our point. 
[Insert Figure 7]

A firm whose production frontier is more concave will react less to changes in the market price of risk (moving typically from point $A$ to point $B_{\text {low }}$ in Figure 7 ) and therefore will need little change in its portfolio of projects and activities. On the other hand, a firm whose production frontier is less concave will see its optimal project mix change more (typically from point $A$ to point $\left.B_{\text {high }}\right)$.

To indirectly measure firm flexibility, we regress the annual change of position in the $(S C O R, E)$ space on the annual change in the market price of risk. We will then link firm flexibility to the use of financial derivatives as our prediction is that more flexible firms are heavier users of financial risk management products.

\subsection{Data sources and construction}

We build a data set from Standard and Poor's 500 index list of companies. We consider all firms present in the index for the whole period 1993-2004, with annual accounting information and stock market information (from Annual Reports, Compustat, Bloomberg and CRSP), as well as hedging and managerial shareholding and option ownership from the EDGAR US Database. ${ }^{14}$ In the end, 269 companies survived our screening criteria. The distribution of firms across industries is given in Table 1.

To compute the flexibility factor, we first measure the annual change $\Delta P_{i}$ in a firm $i$ position in the $(S C O R, E)$-space by the Euclidian distance between the firm positions in two adjacent periods, scaled by the firm market value $V_{i}$ to control for size, that is:

$$
\Delta P_{i t} \equiv \sqrt{\left(S C O R_{i t}-S C O R_{i, t-1}\right)^{2}+\left(C F_{i t}-C F_{i, t-1}\right)^{2}} / V_{i t}
$$

where $S C O R_{i t}=V_{i t} * \sigma_{M} * \beta_{i t}$, with $\sigma_{M}$ being the volatility of market returns, computed historically over the last two hundred trading days, and $\beta_{i t}$ being the beta of cashflows for firm $i$ in period $t$. We then run a linear regression of the change in a firm's position $\left(\Delta P_{i t}\right)$ on the annual change in the market price of risk $\left(\Delta \theta_{t}\right)$ over the period 1993-2004, that is:

$$
\Delta P_{i t}=\alpha_{i}+\gamma_{i} \Delta \theta_{t}+\varepsilon_{i t}
$$

where $\Delta \theta_{t}=\theta_{t}-\theta_{t-1}$, with $\theta_{t}$ given by (11). The regression coefficient $\gamma_{i}$ is our measure of flexibility for firm $i$.

To measure the use of financial instruments, we collected from the EDGAR database the number of risks hedged by each firm as defined by US regulations: equity risk, commodity risk,

\footnotetext{
${ }^{14}$ For the determination of managerial shareholding and option ownership, we analysed the portfolio of the top five executives of the firm as in Ofek and Yermack (2000).
} 
exchange rate risk, and interest rate risk. The first three are considered operational and the last one financial.

\subsection{Estimation of the link between flexibility and hedging}

Before assessing the link between flexibility and the use of financial derivatives at the firm level we want to see if industries that are less flexible hedge less. To perform the analysis, we use the industry categories of Table 1 as well as a reference category called conglomerates. It is known that conglomerates are heavy users of financial derivatives. It is then instructive to see how they rank in terms of flexibility.

\subsubsection{Industry analysis}

We compute a given industry flexibility by the $V_{i}$-weighted average of flexibility measures $\gamma_{i}$ (from regressions (13)) of the firms in that industry. To compute the aggregate use of derivatives by the industry, we use 0-1 variables indicating if a firm hedges one of the four risks mentioned above to obtain the number of risks hedged per firm and then weight these numbers by the ratio of the market value of the firm over the market value of the industry.

Table 2 presents the ranking of the twelve industries in terms of their estimated flexibility level $\gamma$, from the most flexible industry (Utilities) to the least flexible (Construction). The other columns of the table show the market-value weighted average number of operational risks (equity, commodity, and foreign exchange) that firms in that industry hedge through the use of derivative contracts as well as the average number of total risks (operational plus interest rate) hedged.

It is clear from Table 2 that the six most flexible industries (Utilities to Service) are those that hedge the greater number of operational risks using financial derivative contracts. Although the ranking differs slightly when we add the use of interest risk derivatives, the same six most flexible industries remain the top six users of derivative contracts.

Figure 8 illustrates graphically the link between average industry flexibility and average number of operational risks hedged (a similar picture is obtained when the total number of risks is used). The linear relationship is of positive slope, which is significant at the five-percent level, and no industry appears misclassified.

\section{[Insert Figure 8]}

\subsubsection{Analysis at the firm level}

In our second set of empirical results, we examine the relationship between the estimated flexibility level $\gamma_{i}$ and the number of operational risks hedged at the firm level in 2004. The number of firms in the sample is reduced to 238 as we dropped the 31 firms in the financial industry since some 
variables (quick ratio, foreign sales and reserves) are not computed in the same way as in other industries. Of the firms in the sample, $29.8 \%$ hedge no operational risk, $50 \%$ only one risk, $18.5 \%$ two risks, and $1.7 \%$ hedge all three risks.

We use a ranked probit approach. The dependent variable is the number of operational risks that a firm hedges. Therefore, this variable takes the value $0,1,2$ or 3 . We use the following explanatory variables. First and foremost we want to include the variables that previous studies have used to explain the use of financial derivatives by firms to hedge risk. These include the quick ratio (current assets minus inventories divided by current liabilities), the percentage of foreign sales over the total sales, and the carryforward of net operating losses over the total assets: the higher the first ratio is, the less need there is for a firm to hedge; a firm with significant foreign operations will be subject to currency risk and will therefore be more likely to use foreign exchange derivatives; finally, the last variable measures the tax benefit that can be obtained by carrying forward losses. These three variables are the traditional measures included in hedging studies for leverage, foreign exposure and convexity of the tax schedule (see Graham and Rogers 2002, Allayannis and Weston 2001, Allayannis and Ofek 2001, Graham and Smith 1999). Another variable related to the use of financial derivatives is the size of the firm (see Nance et al. 1993) and we measure it by the logarithm of the firm assets.

We estimate the probit model by maximum likelihood. ${ }^{15}$ The results are reported in Table 3 , where a coefficient (with standard error in parentheses) refers to the impact of that variable on the probability that the firm hedges a greater number of operational risks. All four variables above come out with the expected sign and are significant at close to the $5 \%$ level, especially after controlling for the industry effect. Therefore, our analysis confirms the results that previous studies on the motives for hedging have put forward. Moreover, the results in Table 3 show quite clearly that flexibility, which is a 10-year average value characterizing the shape of a firm's efficient frontier, has a statistically significant positive impact on the number of operational risks hedged. This result, together with the previous ranking of industry flexibility and use of derivatives, supports our hypothesis that a firm's sensitivity to the market price of risk is a strong determinant of the use of financial derivatives, in addition to the traditional reasons for hedging such as leverage, foreign exposure and convexity of the tax schedule. To capture the role of financial risk management in alleviating coordination problems we introduce the number of business segments in a firm. This is certainly an imperfect measure of coordination costs but it indicates that the hierarchical structure is important over and above the mere size of the firm. Its clear significance reinforces the link between hedging and the complexity of the firm.

We present also results with a control for the industry to which a firm belongs. In this case

\footnotetext{
${ }^{15} \mathrm{~A}$ full description of the variables included in the probit is given in the appendix.
} 
we prefer not to include business segments. ${ }^{16}$ The results remain robust and are practically the same as without the control for industry.

We have also included in the probit model other variables that previous studies have used to explain hedging such as dividend policy, the long-term debt position of the firm, the book-tomarket ratio, and the security holdings of the managers in the firm. None of those is significant at any reasonable level of confidence.

\section{Discussion}

In this section we extend the analysis in different directions. We first discuss extensions of the basic risk model, then we point to the problems of acquiring the proper information to draw the efficient frontier, and finally we mention some implications of our analysis from an industrial organization perspective.

\subsection{Extensions of the basic risk model}

To show that the approach is not limited to the simple risk model analyzed above, we briefly discuss two important extensions. First, we account for the fact that not all risks are priced by the market. This will not prevent the firm from optimizing, as we will explain. Second, and more importantly, we set the trade-offs between expected cashflows and risk in a dynamic framework through a general stochastic discount factor. This formulation will be compatible with many risk model specifications and encompass the linear multifactor model specified in the previous section.

\subsubsection{The case of non-valued risks}

We have assumed until now that all the risk factors have a market price, so that firm value maximization is achieved at the optimal tangency point between the iso-value hyperplane and the possibility frontier. When the market does not value some risks that are nevertheless taken into consideration by a firm, the valuation problem is different.

We can illustrate this situation with two risk factors: the first is valued by the market and is represented by the market portfolio while the second is managed by the firm at some cost but is diversifiable for an outside investor so that its market value is zero. At what optimal

\footnotetext{
${ }^{16}$ The number of segments was collected in the annual reports of the firms. Given how Compustat classifies a company's industry it would be econometrically unsound to include both the number of business segments and industry control dummies in the same regression. For instance Compustat has one industry category called "non classified" that clearly includes the large conglomerates purely on the basis of the number of business segments. Also there are industries where the choice of business segments is more refined than in other industries and the number of business segments to report is determined by the firm (see Harris, 1998), which induces a systemic bias in the number of business segments across industries.
} 
level should a firm manage this non-valued risk? Each level of non-valued risk corresponds to a projected transformation possibility frontier in the space expected value - market-valued risk, namely $H\left(E, S C O R_{M} \mid S C O R_{N V}\right)=0$, where $S C O R_{N V}$ is the level of non-valued risk taken or assumed by a firm. Under some reasonable assumptions about the non-valued risk (including the existence of a unique global maximum), there is one best or maximal transformation possibility frontier in the space expected value - market-valued risk, namely $H\left(E, S C O R_{M} \mid S C O R_{N V}^{*}\right)=0$. The tangency point between the highest iso-value line and this maximal frontier gives the maximal market value of a firm. ${ }^{17}$

\subsubsection{An Intertemporal Framework}

In the simple risk model we specified earlier, we have sidestepped the problem of computing the present value of intertemporal cashflows by assuming a flat term structure and a constant risk measure over time. Therefore, the transformation possibility frontier did not change over time. In a more realistic setting where risk and return change over time, we need to compute at each point in time, say $t$, an efficient frontier $H_{t}\left(E_{t}, S C O R_{t}\right)=0$, where $E_{t}$ and $S C O R_{t}$ group all the conditional expected values and scaled correlations. The extension to an intertemporal framework can be set in an Arrow-Debreu type economy or in a world with a general stochastic discount factor. In such intertemporal extensions, the price of risk and the price of time will play a role in the marginal trade-offs the firm will engage in, both across states of nature and periods.

To be as general as possible, we need not specify a linear risk model. We can rely on the existence of a stochastic discount factor, say $m_{t, T}$, which gives the value in $t$ of a cashflow in $T$, in the absence of arbitrage opportunities. The value in $t$ of any project within a firm with associated cashflows $C_{t+1}, \cdots, C_{T}$ from $t+1$ to $T$ is then given by:

$$
P_{t}=E_{t}\left[m_{t, t+1} C_{t+1}+\ldots+m_{t, T} C_{T}\right]
$$

By the covariance formula, we can rewrite this expression as the sum of two distinct blocks, one for products of expectations, the other for covariances:

$$
P_{t}=E V_{t}+C O V_{t}
$$

with:

\footnotetext{
${ }^{17} \mathrm{~A}$ parallel can be drawn with the production function using a non-valued or zero-cost input, such as water or air. If production affects the quality of this input, there will be an optimal amount of activity, say in terms of quantity of pollutants rejected, that will be compatible with maximizing profit. Similarly, there will an optimal amount of non-valued risk that a firm should take or assume in order to maximize its market value in the space expected value-market-valued risk. In so doing, a firm optimally manages this non-valued risk.
} 


$$
\begin{aligned}
E V_{t} & =E_{t}\left[m_{t, t+1}\right] E_{t}\left[C_{t+1}\right]+\cdots+E_{t}\left[m_{t, T}\right] E_{t}\left[C_{T}\right] \\
C O V_{t} & =\operatorname{Cov}_{t}\left(m_{t, t+1} C_{t+1}\right)+\cdots+\operatorname{Cov}_{t}\left(m_{t, T} C_{T}\right)
\end{aligned}
$$

The expectation terms $E_{t}\left[m_{t, \tau}\right]_{\tau=t+1}^{T}$ provide the prices of zero-coupon bonds for corresponding horizons $\tau=t+1, \cdots, T$. An efficiency frontier can then be defined in terms of $\left(E_{t}, C O V_{t}\right)$ as before, but now the frontier will change at each period depending on the evolution of the term structure of interest rates and of the risk measures embedded in the stochastic discount factors. Since all quantities have been discounted at time $t$ accounting for both the values of time and risk in cashflows over time and states of nature the iso-value lines will have a slope of one. Of course the analysis of the trade-offs between expected cash flows and risk or between different risks becomes more involved but remains possible once a specific content is given to the stochastic discount factor through a model. ${ }^{18}$

\subsection{Caveats on information acquisition}

In deriving the transformation possibility frontier between the expected value of projects and their risk, we have assumed away technical or informational issues. Such issues could prevent a chief executive officer from implementing the necessary trade-offs. We will sketch below the main obstacles such as incomplete and asymmetric information, indivisibility and transaction costs.

A first obvious problem is the significant data collection implied by the dimension of the problem. Projects are numerous in a firm and obtaining the corresponding cashflows over time is no small task. The information collected is also likely to lack precision. Therefore, the frontier may be derived under imprecise and potentially incomplete information, and uncertainty will prevail as to its exact position. This uncertainty will directly affect determination of the optimal mix of production and risk management activities.

A parallel with mean-variance optimization in asset allocation will help us gauge the extent of the problem. It is well known in this literature that small changes in the assumed distribution of asset returns often imply large changes in the optimized portfolio. Many portfolios may be statistically as efficient as the ones on the efficient frontier. Several statistical solutions have been proposed to account for the variability of the efficient frontier (see Michaud, 1998) and

\footnotetext{
${ }^{18}$ When the stochastic discount factor corresponds to the CAPM or the linear multifactor model described in section 2.2, the trade-offs can be expressed between expected cashflows and scaled correlations. To obtain a similar separation of parameters leading to the use of scaled correlations with the general specification in (14), more structure is needed in the stochastic discount factor. For example, one can extend the factor model described earlier to a dynamic factor model where the scaled correlations will change over time, assuming, for simplicity, that the term structure of interest rates is flat.
} 
to increase the stability of the optimal portfolio (Jagannathan and Ma, 2003). Beyond these statistical solutions, one can mitigate the uncertainty associated with a detailed computation of intertemporal cashflows by aggregating projects among various organizational units. This will make the problem of gathering data generally easier given the accounting system already in place and facilitate the optimization process.

Asymmetric information could also prevent a firm from attaining the project mix that maximizes its value. Adverse selection and moral hazard problems can impede the process of gathering information at every level of a firm's hierarchy (see Williamson 1967). Managers may propose projects that have been selected on criteria other than maximizing firm value. The collection of projects from which the frontier is drawn may not, therefore, be the right one and the final mix of projects will be suboptimal. Solutions for these problems are the usual incentive schemes that will help elicit the right information.

Another important difficulty in drawing up a possibility frontier for a firm lies in the indivisibility of real assets. In portfolio theory with infinitely divisible financial assets, it is always possible to be arbitrarily close to the efficient point on the frontier. With real activities, some projects must be undertaken completely or not at all. A numerical search for the optimal mix of activities has to proceed differently, but it is still possible to arrive at a frontier. It will not have the smooth appearance that we drew in our graphs but it will keep its optimality property. Similarly, some constraints may be imposed on the minimal size of projects in deriving the optimal frontier.

Transaction costs may explain why a firm does not want to continuously change the optimal mix of projects. For example, premature termination of a project may involve penalties in terms of labor compensation or legal fees. A change in the optimal mix may also be postponed because of fixed costs associated with the disposal of fixed assets. Incorporating these transaction costs in portfolio choice is an extremely difficult theoretical and computational issue. Only partial solutions with specific cost structures, often unrealistic, are available. Transaction costs associated with a change of policy are just one example of sunk or irreversible costs. When a project in under way, managers may induce some changes that will affect its future cashflows; this is another potentially important source of costs.

\subsection{Implications for Industrial Organization Analysis}

Despite its arguably abstract nature, our financial and real risk management model leads to several empirical implications for industrial organization analysis. We discuss below some of our results in the context of this literature.

Our empirical analysis shows that firms with a weakly concave frontier are more likely to use financial risk management tools. An interpretation of this result is that financial derivatives 
facilitate active real asset management. Because obtaining a consensus is more likely to be difficult when changes in the project mix are important, corporations with a more diverse potential project mix are more likely to gain by engaging in financial risk management. Our argument thus suggests that multiindustrial and multinational firms, that have a more diverse project mix than singleindustry single-country firms, as well as firms with significant growth options, will be heavier users of derivatives. Indeed, Geczy et al. (1997) find that firms with extensive foreign exchange-rate exposure (like multinational firms) are more important users of derivatives; He and Ng (1998) maintain the same in the case of conglomerates; and Nance et al. (1993) find that firms with significant growth options use more derivatives.

Larger corporations are more likely faced with more challenging coordination problems simply because of their wider dispersion of real assets and extensive distribution of responsibilities. Indeed, Nance et al. (1997), Mian (1996) and Graham and Rogers (2002) have shown that financial risk management procedures and products, such as forwards, futures, swaps, and options, are more common in larger firms while almost non existent in smaller firms. ${ }^{19}$ These empirical regularities contradict theories in which the value of financial risk management is based upon the reduction of the cost of financial distress,${ }^{20}$ but are clearly compatible with the predictions of our model. To justify the greater use of financial derivatives by large firms, previous studies have invoked the large costs of setting up a risk management function. We also propose a cost argument but link these costs to reorganization and coordination.

Another test would be to compare corporations where the number of executives who have a say in project approval is large with corporations where that number is small. Because financial risk management is more valuable for corporations that have major coordination problems, our model predicts also that firms with a larger number of executives involved in project selection will use more financial risk management techniques. We are not aware of any study on that topic.

Finally, our model leads to a renewed consideration of the use of financial hedging instruments by firms subject to regulated or self-imposed financial constraints, such as value-at-risk or cashflow-at-risk constraints. Indeed Stulz (1996) proposes "a somewhat different goal for corpo-

\footnotetext{
${ }^{19}$ See also the results from the Wharton-Chase survey (1995) and the Wharton-CIBC Wood Gundy survey (1996) as mentioned in Stulz (1996, page 9): "Whereas $65 \%$ of companies with a market value greater than $\$ 250$ million reported using derivatives, only $13 \%$ of the firms with market values of $\$ 50$ million or less claimed to use them."

${ }^{20}$ Stulz (1996) writes: "The primary emphasis of the [corporate risk management] theory is on the role of derivatives in reducing the variability of corporate cashflows and, in so doing, reducing various costs associated with financial distress. The actual corporate use of derivatives, however, does not seem to correspond closely to the theory. For one thing, large companies make far greater use of derivatives than small firms, even though small firms have more volatile cashflows, more restricted access to capital, and thus presumably more reason to buy protection against financial trouble. Perhaps more puzzling, however, is that many companies appear to be using [financial] risk management to pursue goals other than variance reduction."
} 
rate risk management - namely the elimination of costly lower-tail outcomes - that is, designed to reduce the expected costs of financial troubles while preserving a company's ability to exploit any comparative advantage in risk-bearing it may have" (page 8, emphasis in original). ${ }^{21} \mathrm{We}$ showed (Figure 4) that financial risk management could, through the use of zero-value contracts, allow firms to meet those constraints without sacrificing firm value. Our model suggests therefore that, because they are typically subject to stringent financial constraints of the VaR and CaR types, firms in sectors such as financial services and utilities will be among the heavier users of derivatives and other financial risk management instruments. The reason we elicit here for this significant use of financial risk management procedures and products is clearly different from that proposed by Stulz. Indeed, the significant growth of securitization markets suggests that firms in financial services use financial instruments more than manufacturing firms.

\section{Conclusion}

We developed a framework to show that both real and financial risk management can add value to a firm. Contrary to the current academic view of risk management, which makes it a special purpose function of a corporation rather than an integral part of decision making, we proposed a characterization of firms as nexus of projects defined by their expected cashflows and risk, where risk management activities appear alongside operations in maximizing firm value.

We were then able to define a transformation possibility set for a firm. In this context, the object of production and operations management is to raise expected cashflows while real risk management aims to lower risk. By choosing the projects to invest in, managers search for efficiency, that is attaining the frontier of possibilities, as well as for optimality, that is reaching the point on that frontier that maximizes firm value given the market prices of risk factors. Conflicts may arise in the firm when managers do not view the projects as having the same potential contribution to firm value. This is where financial risk management can help a firm in maximizing value.

The facilitating role of financial risk management is crucial whenever changes in the market prices of risk factors induce important real changes in the optimal set of projects. Our empirical strategy rests precisely on identifying how much a firm reacts to changes in risk prices: a firm flexibility depends on the relative concavity of its possibility frontier. Using time series from 1993 to 2004, we measured this flexibility factor for 269 large U.S. firms. We then related flexibility to the use of financial derivative instruments to hedge operational risks. First, we found that there is a strong relationship at the industry level between the aggregate measure of flexibility and the use of derivatives. Second, we constructed a probability model at the firm level to explain the number

\footnotetext{
${ }^{21}$ Stulz's surprising proposal came in reaction to “. . . the popularity of a practice known as 'selective' as opposed to 'full-cover' hedging. [...] Such a practice seems inconsistent with modern risk management theory."
} 
of operational risks hedged. We found a strong and significant role for the flexibility factor in this relation, even after controlling for firm size, leverage, foreign exposure, and convexity of the tax schedule, as well as for industry effects. We could then conclude that the flexibility factor, a measure of the concavity of the possibility frontier, is an important determinant of a firm's use of financial risk management instruments.

Our interpretation of this relationship is that more flexible firms are likely to face important coordination problems in maximizing their value and that financial risk management through derivatives facilitates coordination. It is through such facilitation that financial risk management indirectly contributes to firm value, especially in a context where real asset management activities are decentralized. Our representation of operations and risk management within a firm therefore supports the view that financial risk management can add value even in a world with no taxes, no financial distress costs, and no information asymmetry.

Access to micro data sets on firms could lead to the estimation of risk-reward frontiers, that is, frontiers expressed in terms of risk and expected cashflows. This could lead to a refined analysis of the links between characteristics of the efficient frontier, market parameters and organizational characteristics of the firm. This opens a fascinating new avenue to study the relationship between firm value and risk management. 


\section{References}

[1] Allayannis, G. and J. Weston (2001), "The Use of Foreign Currency Derivatives and Firm Value," Review of Financial Studies 14: 243-276.

[2] Allayannis, G. and E. Ofek (2001), "Exchange Rate Exposure, Hedging, and the Use of Foreign Currency Derivatives," Journal of International Money and Finance 20: 273-296.

[3] Becker, G.S. and K.M. Murphy (1993), "The Division of Labor, Coordination Costs, and Knowledge,"in Human Capital: A Theoretinal and Empirical Analysis, with sSpecial Reference to Education, 3rd ed., by G.S. Becker. Chicago: Univ. of Chicago Press.

[4] Bessembinder, H. (1991), "Forward Contracts and Firm Value: Investment Incentive and Contracting Effects," Journal of Financial and Quantitative Analysis 26: 519-532.

[5] Block, S.B., and T.J. Gallagher (1986), "The Use of Interest rate Futures and Options by Corporate Financial Managers," Financial Management 15: 73-78.

[6] Bodnar, G.M., G.S. Hayt and R.C. Marston (1998), "Wharton 1998 Survey of Risk Management by US Non-Financial Firms," Financial Management 27: 70-91.

[7] Bolton, P. and M. Dewatripont (1994), "The Firm as a Communication Network," Quarterly Journal of Economics 109: 809-839.

[8] Booth, J.R., R.L. Smith and R.W. Stolz (1984), "The Use of Interest Futures by Financial Institutions," Journal of Financial Economics 8: 3-29.

[9] Boyer, M. and J. Robert (2006), "Organizational Inertia and Dynamic Incentives," Journal of Economic Behavior and Organization 59(3), March 2006, 324-348.

[10] Breeden, D., and S. Viswanathan (1996), "Why Do Firms Hedge? An Asymmetric Information Model," Duke University Working paper.

[11] Cummins, J.D. (1976), "Risk Management and the Theory of the Firm," Journal of Risk and Insurance 43: 587-609.

[12] DeMarzo, P. and D. Duffie (1995), "Corporate Incentives for Hedging and Hedge Accounting," Review of Financial Studies 8: 743-771.

[13] Dessein, W., Garicano, L. and R. Gertner (2006), "Organizing for Synergies," mimeo, Graduate School of Business, University of Chicago.

[14] Doherty, N.A. and J.R. Garven (2006), "Noise Hedging and Executive Compensation," mimeo, Wharton School of the University of Pennsylvania. 
[15] Doherty, N.A. and C.W. Smith (1993), "Corporate Insurance Policy: The Case of British Petroleum," Journal of Applied Corporate Finance, 6: 4-15..

[16] Fama, E.F. and M.H. Miller (1972), The Theory of Finance, Hinsdale: Dryden Press.

[17] Froot, K., D. Scharfstein and J. Stein (1993), "Risk Management: Coordinating Corporate Investment and Financing Policies," Journal of Finance 48: 1629-1658.

[18] Gable, L. and B. Sinclair-Desgagné (1997), "Environmental Auditing in Management Systems and Public Policy", Journal of Environmental Economics and Management 33: 331-346.

[19] Garicano, L. (2000), "Hierarchies and the Organization of Knowledge in Production," Journal of Political Economy 108: 874-904.

[20] Geczy, C., B. Minton and C. Schrand (1997), "Why Firms Use Currency Derivatives," Journal of Finance 52: 1323-1354.

[21] Graham, J.R. (2003), "Taxes and Corporate Finance: A Review," Review of Financial Studies 16: 1075-1129.

[22] Graham, J.R. and D.A. Rogers (2002), "Do Firms Hedge in Response to Tax Incentives?," Journal of Finance 57: 815-839.

[23] Graham, J.R. and C.W. Smith (1999), "Tax Incentives to Hedge," Journal of Finance 54: 2241-2262.

[24] Hannan, M.T. and J. Freeman (1984), "Structural Inertia and Organizational Change," American Sociological Review 49: 149-164.

[25] Harris, M.S. (1998), "The Association between Competition and Managers' Business Segment Reporting Decisions," Journal of Accounting Research 36: 111-128.

[26] Hayek, F.A. von (1945), "The Use of Knowledge in Society," American Economic Review 35: 519-530.

[27] He, J. and L. Ng (1998), "The Foreign Exchange Exposure of Japanese Multinational Corporations," Journal of Finance 53: 733-753.

[28] Holton, G.A. (2004), "A New Position on Risk," Futures and Options World, February 44-45.

[29] Holmström, B. and J. Tirole (2000), "Liquidity and Risk Management," Journal of Money, Credit and Banking 32: 295-319. 
[30] Jagannathan, R. and T. Ma (2003), "Risk Reduction in Large Portfolios: Why Imposing the Wrong Constraints Helps," Journal of Finance 58(4), 1651-1685.

[31] Jin, Y. and P. Jorion (2006). "Firm Value and Hedging: Evidence from U.S. Oil and Gas Producers," Journal of Finance, 61: 893-919.

[32] Lessard, D. (1991), "Global Competition and Corporate Finance in the late 1990's," Journal of Applied Corporate Finance 3: 59-72.

[33] MacKay, P. and S.B. Moeller (2006), "The Value of Corporate Risk Management," Journal of Finance, forthcoming

[34] Main, B. (1983), "Corporate Insurance Purchases and Taxes," Journal of Risk and Insurance 50: 197-223.

[35] Mayers, D. and C.W. Smith (1987), "Corporate Insurance and the Under Investment Problem," Journal of Risk and Insurance 54: 45-54.

[36] Mayers, D. and C.W. Smith (1990), "On the Corporate Demand for Insurance: Evidence from the Reinsurance Market," Journal of Business 63: 19-40.

[37] Mehr, R.I. and S.W. Forbes (1973), "The Risk Management Decision in the Total Business Setting," Journal of Risk and Insurance 40: 389-401.

[38] Merton, R. C. (1972), "An Analytic Derivation of the Efficient Portfolio Frontier," Journal of Financial and Quantitative Analysis 7: 1851-1872.

[39] Mian, S.L. (1996). "Evidence on Corporate Hedging Policy," Journal of Financial and Quantitative Analysis 31: 419-439.

[40] Michaud, R. (1998), "Efficient Asset Management, A Practical Guide to Stock Portfolio Optimization and Asset Allocation," HBS Press.

[41] Modigliani, F. and M.H. Miller (1958), "The Cost of Capital, Corporation Finance, and the Theory of Investments," American Economic Review 48: 261-297.

[42] Mookherjee, D. (2006), "Decentralization, Hierarchies, and Incentives: A Mechanism Design Perspective," Journal of Economic Literature 64: 367-390.

[43] Nance, D.R., C.W. Smith and C.W. Smithson (1993), "On the Determinants if Corporate Hedging," Journal of Finance 48: 267-284.

[44] Ofek, E. and D.Yermack (2000). "Taking Stock: Equity-Based Compensation and the Evolution of Managerial Ownership," Journal of Finance, 55: 1367-1384. 
[45] Sinclair-Desgagné, B. (1999), "How to Restore Higher-Powered Incentives in Multitask Agencies," Jounal of Law, Economics and Organizations 15: 418-433.

[46] Smith, C.W. and R. Stulz (1985), "The Determinants of Firms' Hedging Policies," Journal of Financial and Quantitative Analysis 20: 391-405.

[47] Smithson, C. and B.J. Simkins (2005), "Does Risk Management Add Value? A Survey of the Evidence," Journal of Applied Corporate Finance 17: 8-17.

[48] Stulz, R.M. (1984). "Optimal Hedging Policies," Journal of Financial and Quantitative Analysis, 19: 127-140.

[49] Stulz, R.M. (1996), "Rethinking Risk Management," Journal of Applied Corporate Finance 9: 8-24.

[50] Stulz, R.M. (2004), Risk Management and Derivatives, Thomson South-Western Publishers.

[51] Titman, S. (2002), "The Modigliani and Miller Theorem and Integration of Financial Markets," Financial Management 31: 1-21.

[52] Tufano, P. (1996), "Who Manages Risk? An Empirical Examination of Risk Management Practices in the Gold Mining Industry," Journal of Finance 51: 1097-1137.

[53] Williamson, O. (1967). "Hierarchical Control and Optimum Firm Size," Journal of Political Economy, 75: 123-138. 


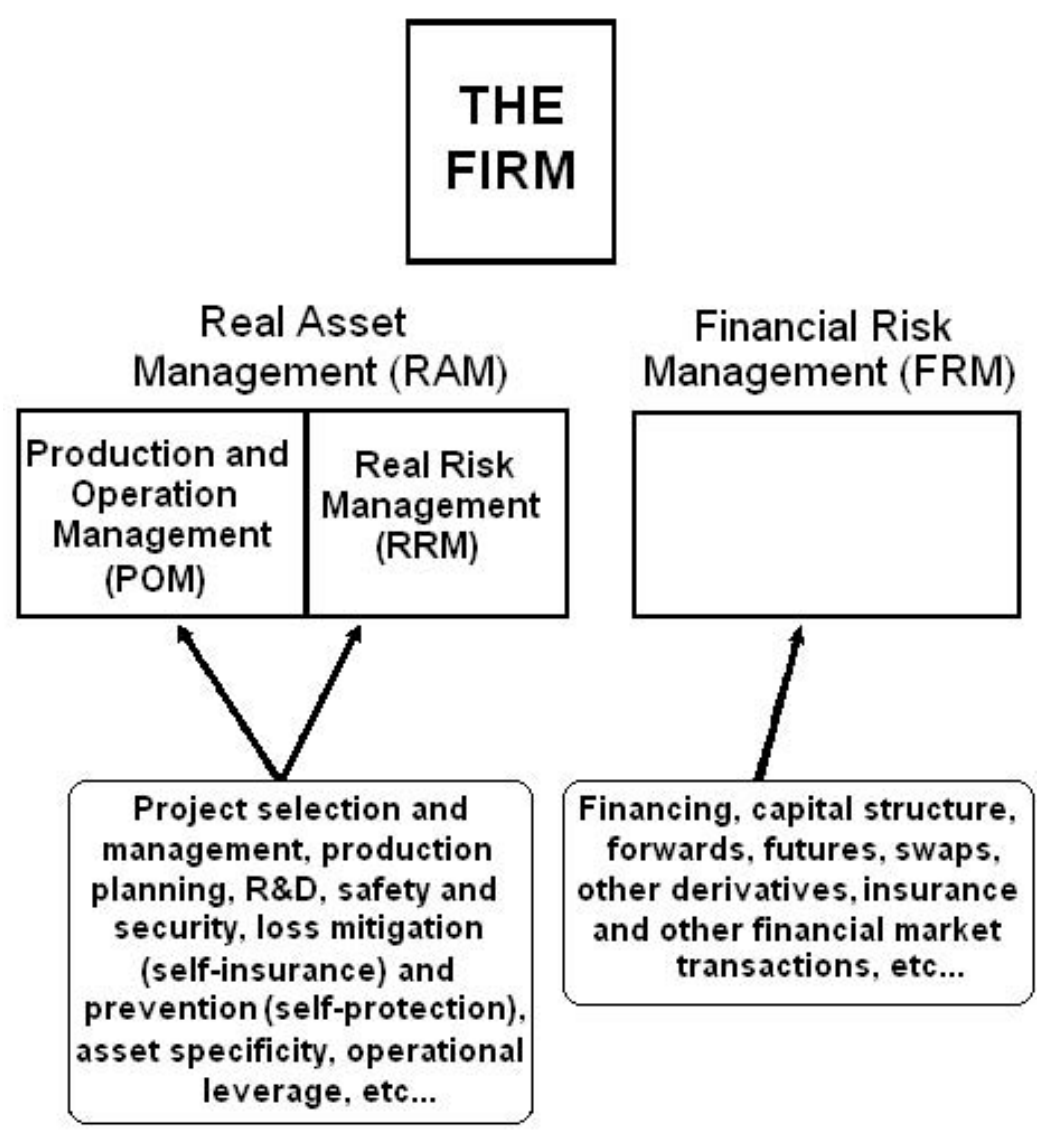

Figure 1: Production and operation management (POM), real risk management (RRM) and financial risk management (FRM) in the firm. 


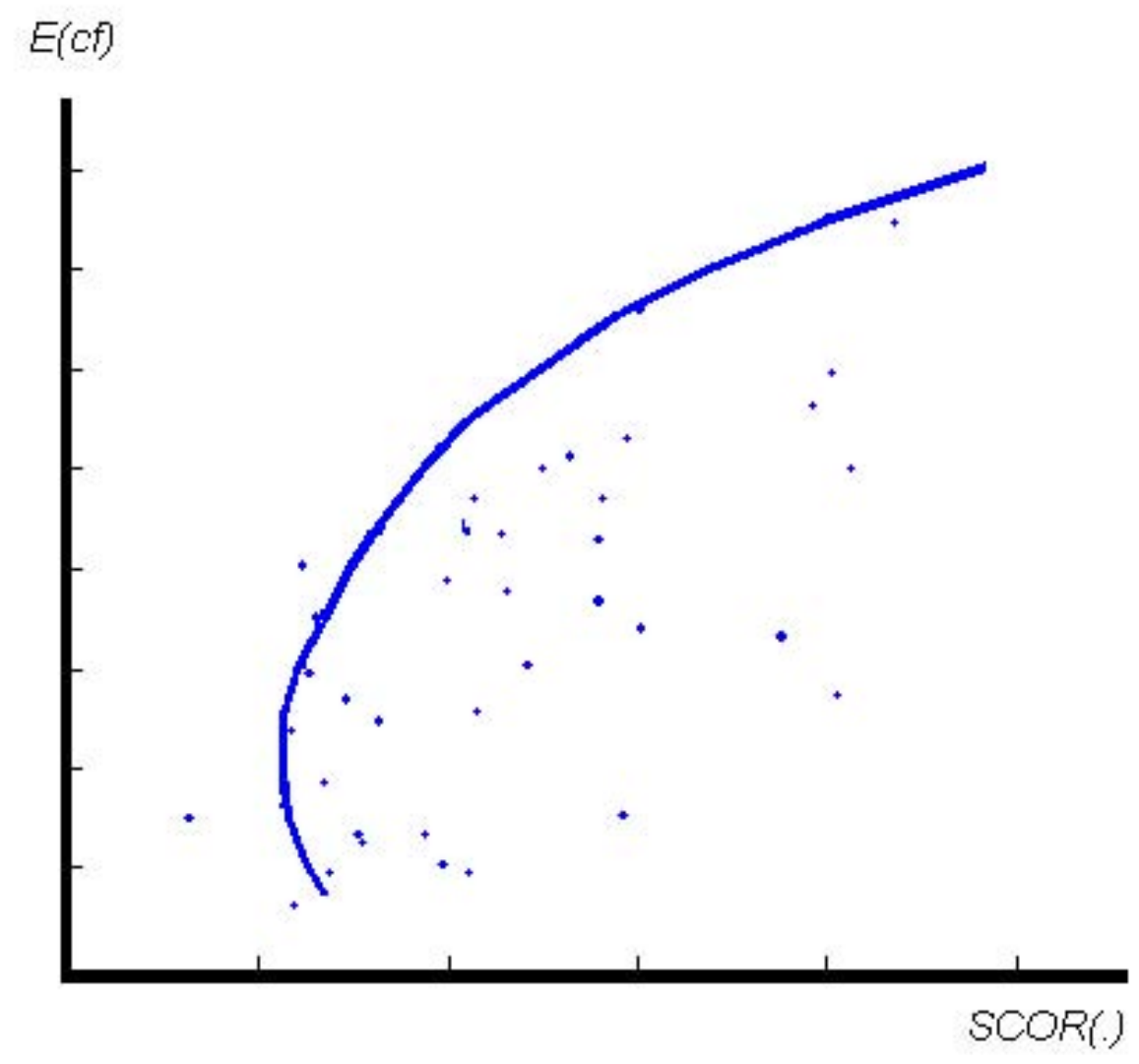

Figure 2: Efficient frontier given the portfolio of projects available to the firm. 


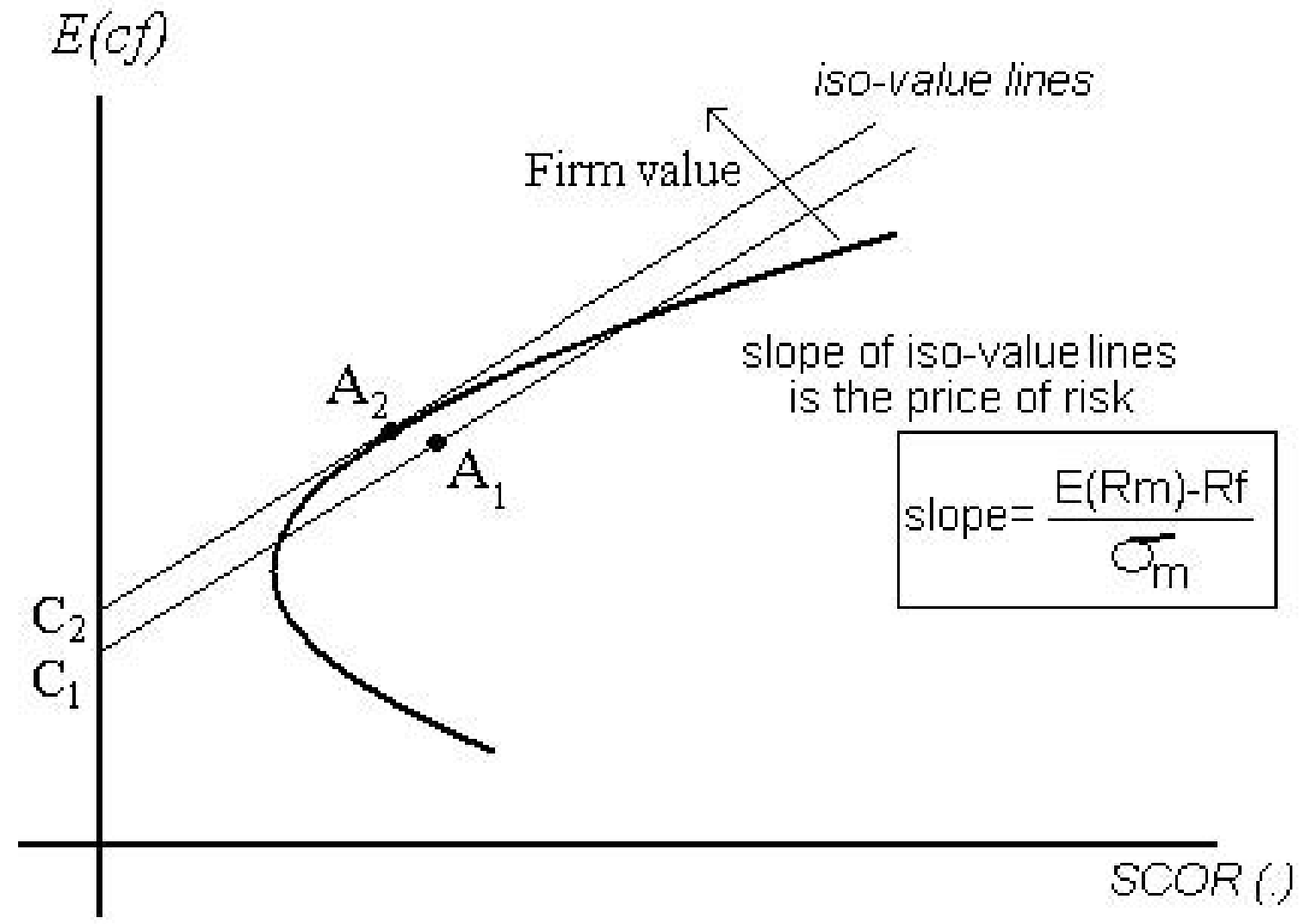

Figure 3: Efficient frontier and value maximization of the firm given the price of risk. 


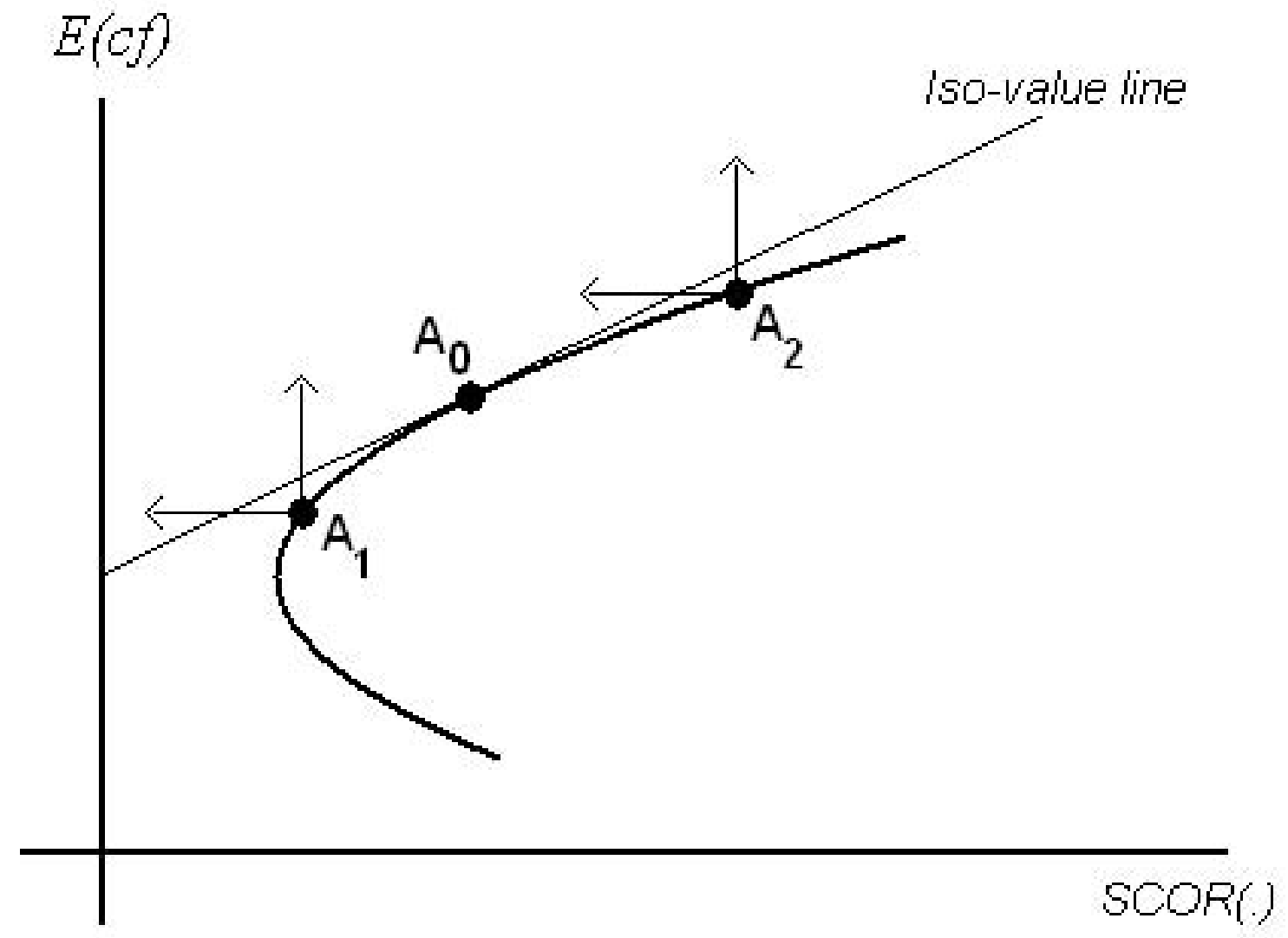

Figure 4: Coordination problems. 


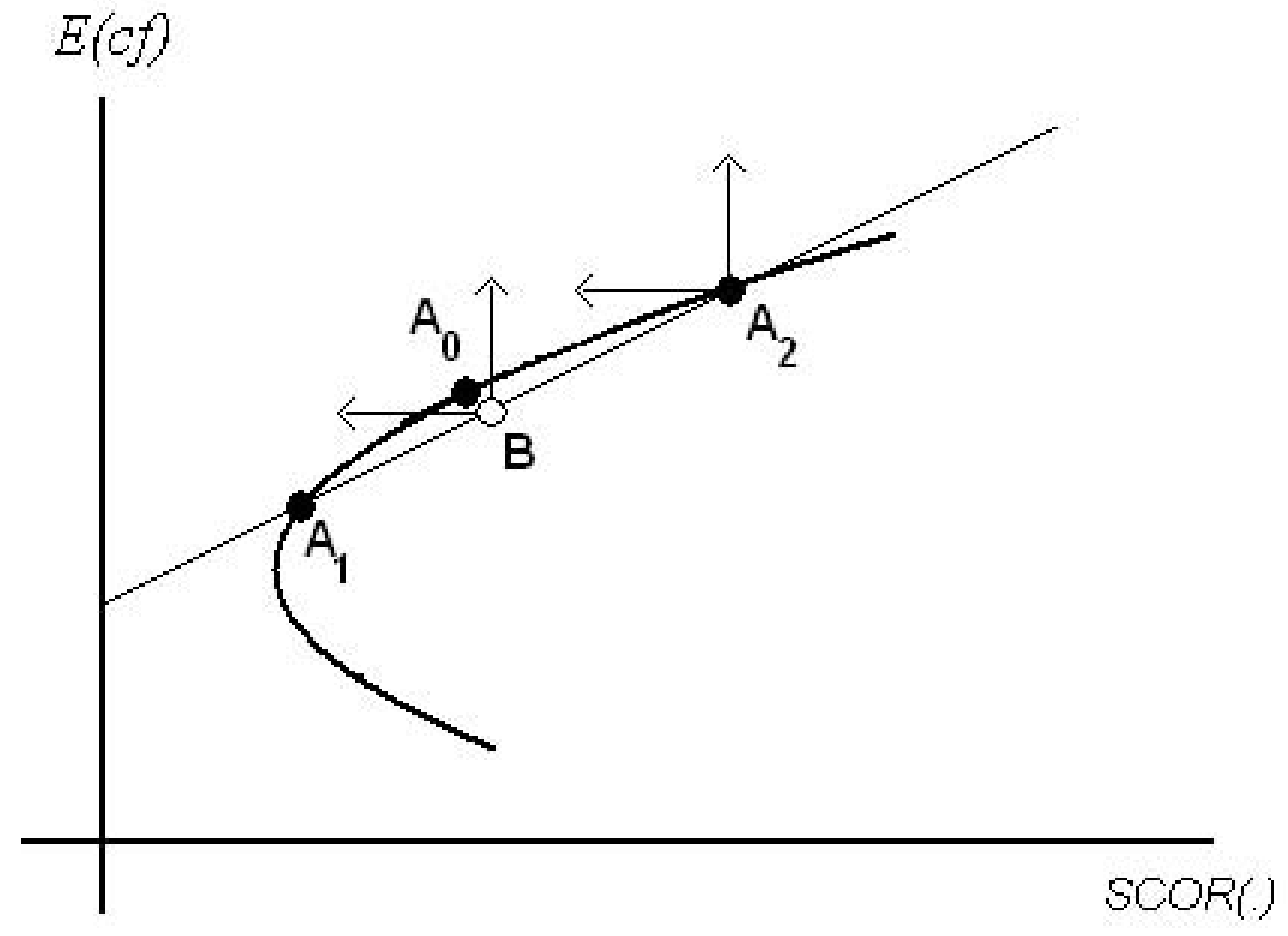

Figure 5: Value of financial risk management. 


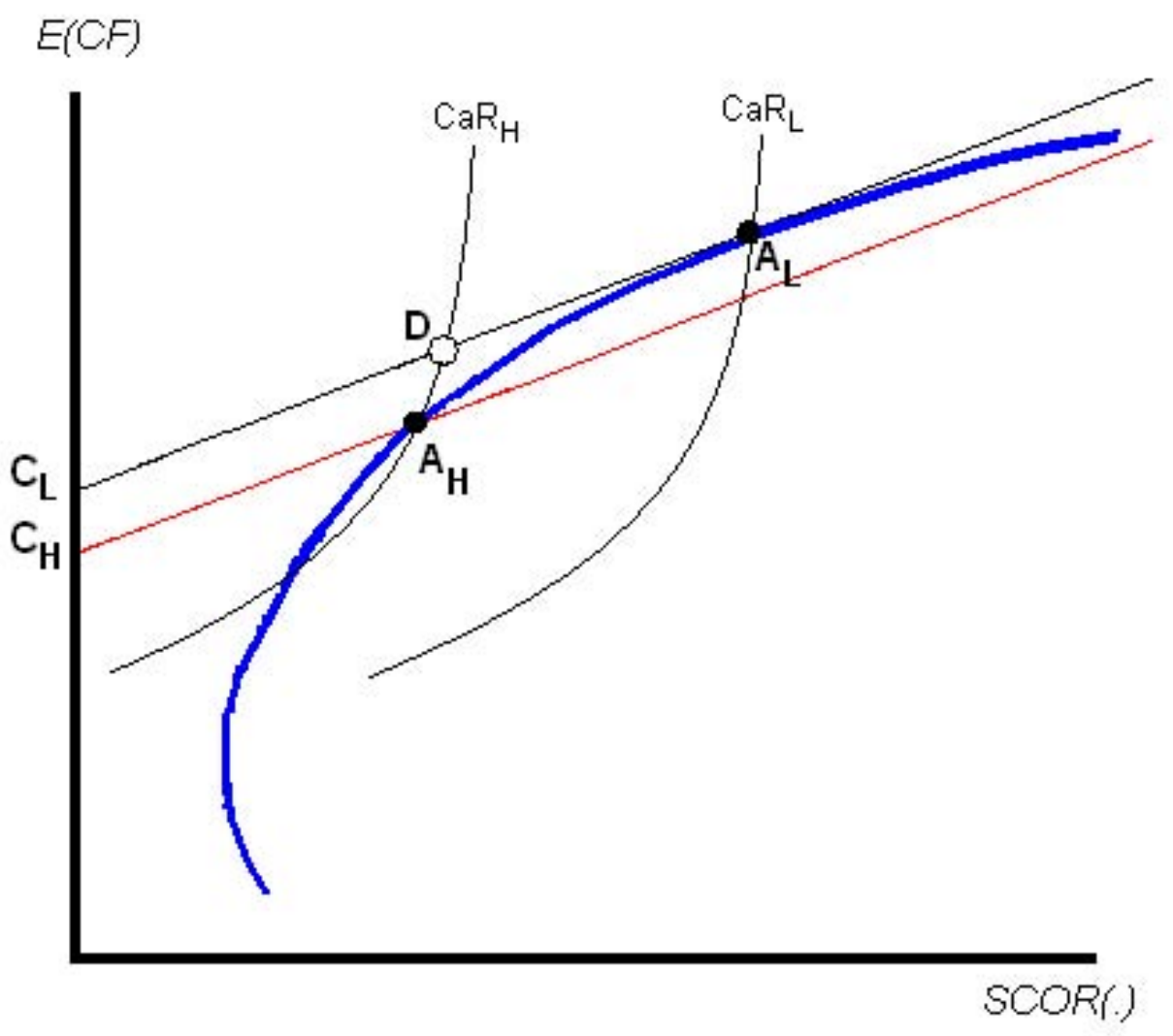

Figure 6: The value of using financial instruments for a firm constrained by $C a R$ requirements. 


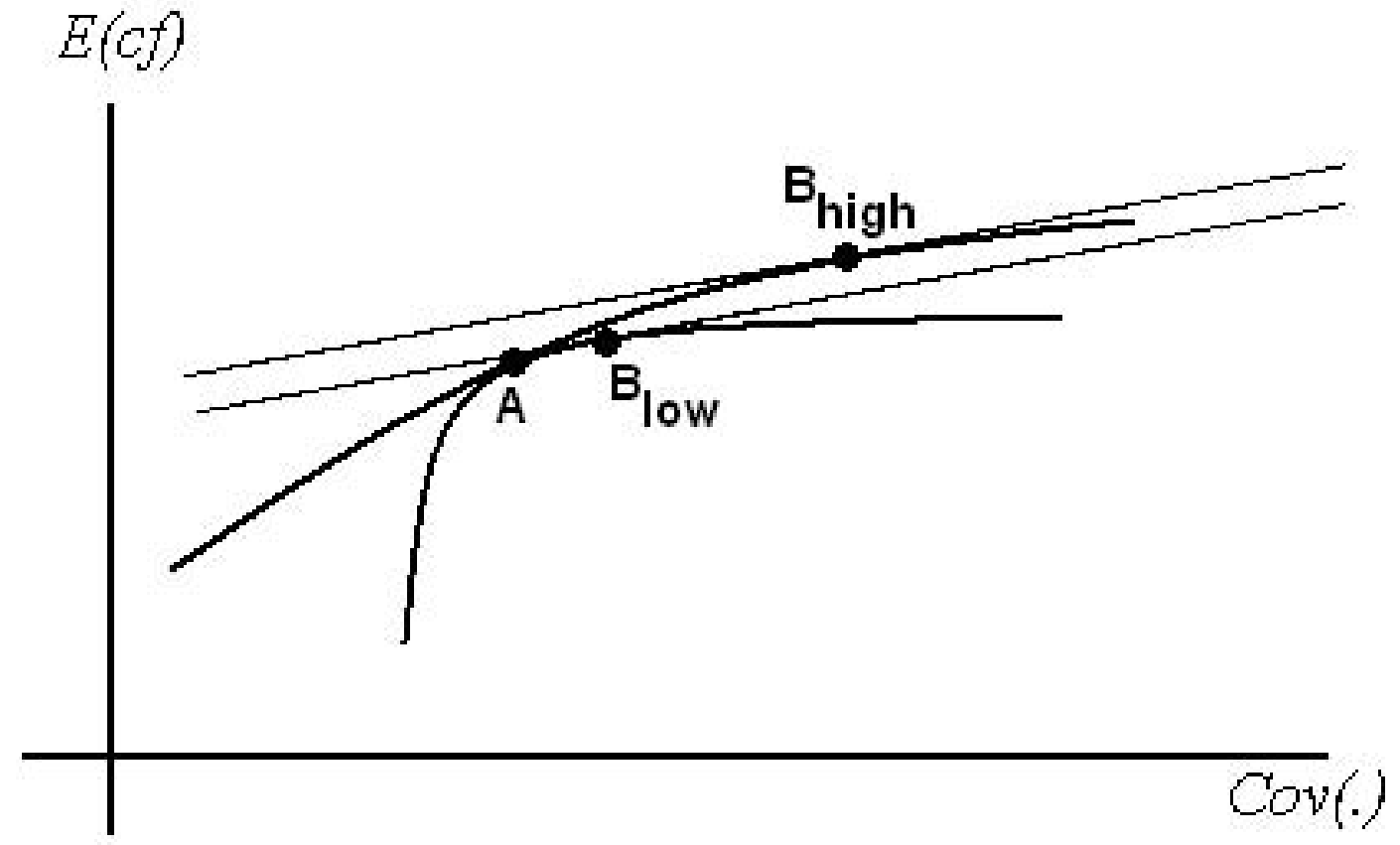

Figure 7: Impact of a change in the market price of risk on low and high production flexibility frontiers. 


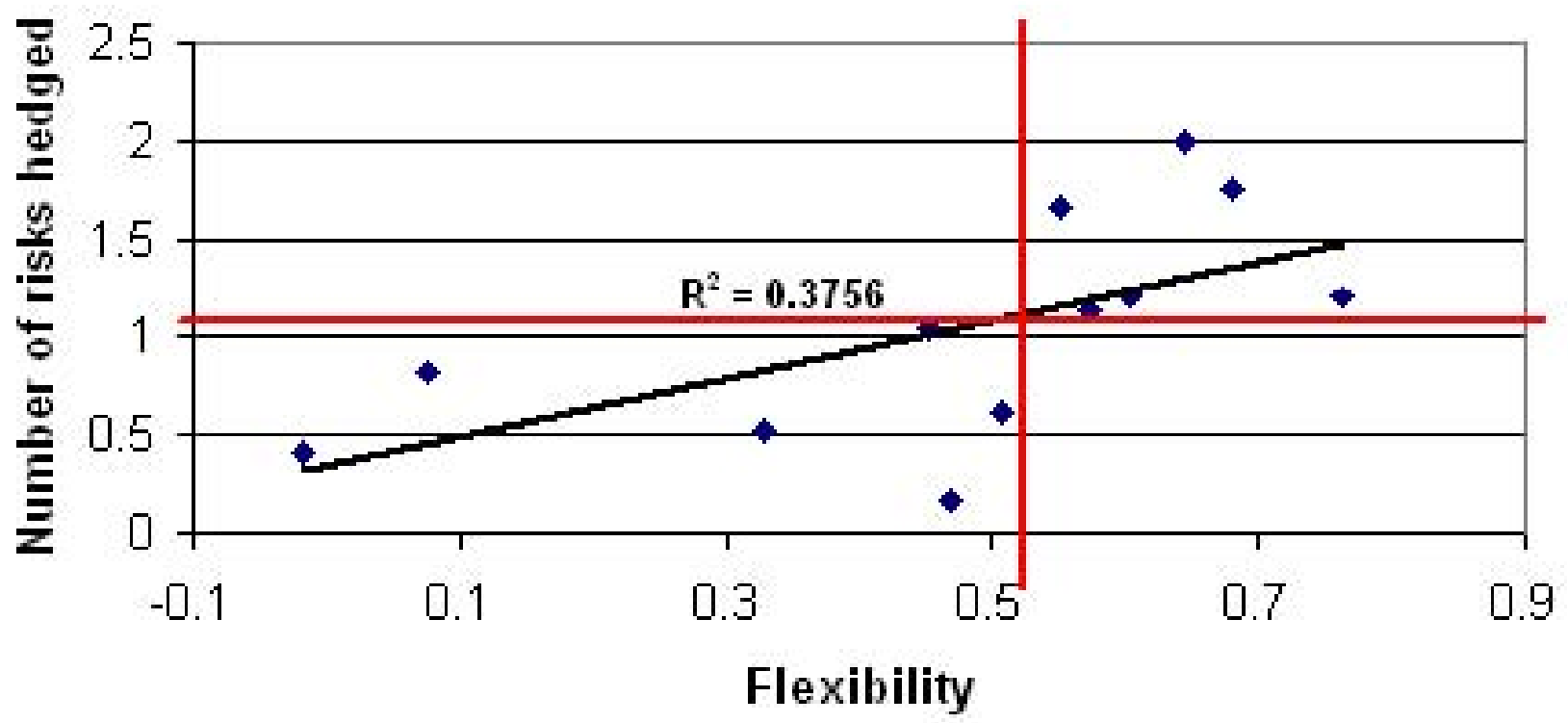

Figure 8: Number of Operational Risks Hedged as a Function of Flexibility by Industry. 


\section{Description of the explanatory variables included in the probit analysis (Table 3)}

- $\log ($ Assets $):$ Logarithm of total assets of the firm.

- Dividend Yield : Dividend paid for the year by the firm divided by its stock price.

- MarketValue/BookValue: Market value of the firm (stock price times the number of issued shares) divided by the book value of the firm.

- Long-term Debt/MarketValue: Value of the long-term debt divided by the market value of the firm.

- R\&D/Assets: Research and development expenses divided by the total assets of the firm.

- Quick Ratio : Value of the currents assets minus the inventories divided by current liabilities.

- Foreign Sales Share: Percentage of the foreign sales over the total sales of the firm.

- NOL carryforward / Assets : Net Operating Losses carryforward over the total assets of the firm.

- Log(Managerial Stock): Logarithm of the stocks market value holding of the top five managers.

- Log(Managerial Option): Logarithm of the options market value holding of the top five managers. 
Table 1. Distribution of firms across industries

\begin{tabular}{cccc}
\hline Industry & SIC & Code & Number of firms \\
\hline Food & $2000-2099$ & 1 & 13 \\
Mining & $1000-1499$ & 2 & 11 \\
Construction & $1500-1999$ & 3 & 4 \\
Manufacturing & $2200-3999$ & 4 & 136 \\
Transportation & $4000-4799$ & 5 & 5 \\
Communications & $4800-4899$ & 6 & 4 \\
Utilities & $4900-4999$ & 7 & 12 \\
Wholesale & $5000-5199$ & 8 & 4 \\
Retail & $5200-5999$ & 9 & 25 \\
Finance & $6000-6599$ & 10 & 31 \\
Service & $7000-9999$ & 13 & 22 \\
Non-Classified & & 14 & 2 \\
\hline
\end{tabular}




\begin{tabular}{|cccccc|}
\hline \multicolumn{1}{|c}{ Table 2. Estimated flexibility } & and use of financial derivative instruments by industry & \\
\hline & Estimated & Weighted number of & & Weighted number & \\
Industry & flexibility & operational risks & Rank & of total risks & Rank \\
& level & hedged & & hedged & \\
\hline Utilities & 0.761 & 1.206 & 5 & 2.111 & 4 \\
Food & 0.679 & 1.758 & 2 & 2.622 & 2 \\
Conglomerates & 0.646 & 2.000 & 1 & 3.000 & 1 \\
Mining & 0.603 & 1.208 & 4 & 2.043 & 6 \\
Financial & 0.574 & 1.130 & 6 & 2.068 & 5 \\
Service & 0.551 & 1.673 & 3 & 2.462 & 3 \\
\hline Retail & 0.508 & 0.619 & 9 & 1.293 & 10 \\
Wholesale & 0.470 & 0.163 & 12 & 1.030 & 11 \\
Manufacturing & 0.451 & 1.028 & 7 & 1.609 & 8 \\
Communications & 0.328 & 0.521 & 10 & 1.521 & 9 \\
Transportation & 0.075 & 0.824 & 8 & 1.824 & 7 \\
Construction & -0.017 & 0.401 & 11 & 1.000 & 12 \\
\hline
\end{tabular}


Table 3. Firm flexibility and number of operational risks hedged

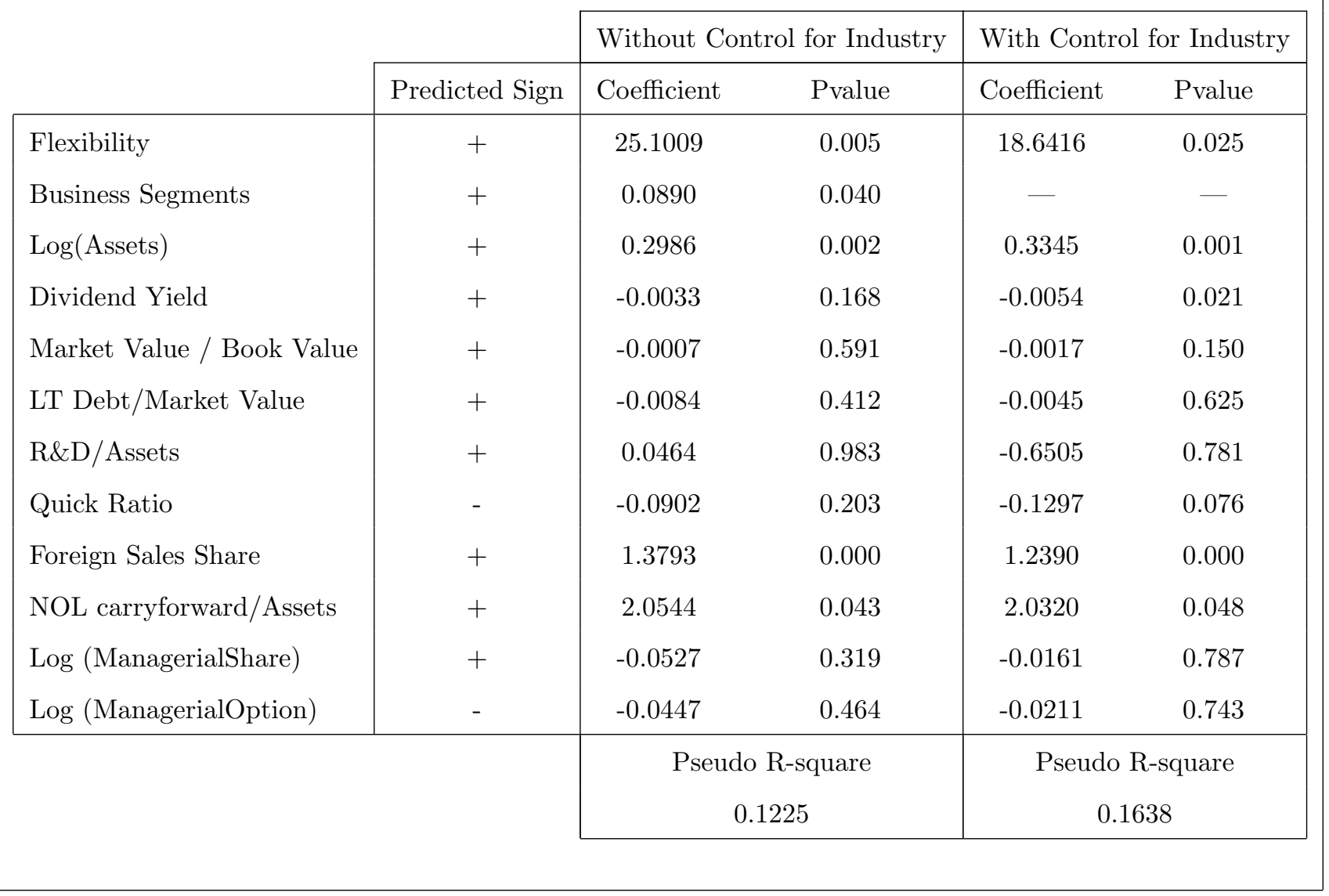

